University of Nebraska - Lincoln

DigitalCommons@University of Nebraska - Lincoln

1990

\title{
Age Estimates and Uplift Rates for Late Pleistocene Marine Terraces' Southern Oregon Portion of the Cascadia Forearc
}

\author{
Daniel R. Muhs \\ U.S.Geological Survey, dmuhs@usgs.gov \\ Harvey M. Kelsey \\ Western Washington University \\ Gifford H. Miller \\ University of Colorado \\ Geoge L. Kennedy \\ Los Angeles County Museum of Natural History \\ Joseph F. Whelan \\ U.S.Geological Survey \\ See next page for additional authors
}

Follow this and additional works at: https://digitalcommons.unl.edu/usgsstaffpub

Part of the Earth Sciences Commons

Muhs, Daniel R.; Kelsey, Harvey M.; Miller, Gifford H.; Kennedy, Geoge L.; Whelan, Joseph F.; and Mclnelly, Galan W., "Age Estimates and Uplift Rates for Late Pleistocene Marine Terraces' Southern Oregon Portion of the Cascadia Forearc" (1990). USGS Staff -- Published Research. 164.

https://digitalcommons.unl.edu/usgsstaffpub/164

This Article is brought to you for free and open access by the US Geological Survey at DigitalCommons@University of Nebraska - Lincoln. It has been accepted for inclusion in USGS Staff -- Published Research by an authorized administrator of DigitalCommons@University of Nebraska - Lincoln. 


\section{Authors}

Daniel R. Muhs, Harvey M. Kelsey, Gifford H. Miller, Geoge L. Kennedy, Joseph F. Whelan, and Galan W. Mclnelly 


\title{
Age Estimates and Uplift Rates for Late Pleistocene Marine Terraces: Southern Oregon Portion of the Cascadia Forearc
}

\author{
Daniel R. Muhs, ${ }^{1}$ Harvey M. Kelsey,${ }^{2}$ Gifford H. Miller,${ }^{3}$ George L. Kennedy,${ }^{4}$ \\ JoSePh F. Whelan, ${ }^{1}$ AND Galan W. MCINELly ${ }^{2}$
}

\begin{abstract}
Marine terraces are prominent landforms along the southern Oregon coast, which forms part of the forearc region of the Cascadia subduction zone. Interest in the Cascadia subduction zone has increased because recent investigations have suggested that slip along plates at certain types of convergent margins is characteristically accompanied by large earthquakes. In addition, other investigations have suggested that convergent margins can be broadly classified by the magnitude of their uplift rates. With these hypotheses in mind, we generated new uranium series, amino acid, and stable isotope data for southern Oregon marine terrace fossils. These data, along with terrace elevations and two alternative estimates of sea level at the time of terrace formation, allow us to determine terrace ages and uplift rates. Uranium series analysis of fossil coral yields an age of $83 \pm 5$ ka for the Whisky Run terrace at Coquille Point in Bandon, Oregon. A combination of amino acid and oxygen isotope data suggest ages of about 80 and $105 \mathrm{ka}$ for the lowest two terraces at Cape Blanco. These ages indicate uplift rates of 0.45-1.05 and 0.81-1.49 m/kyr for Coquille Point and Cape Blanco, respectively. Late Quaternary uplift rates of marine terraces yield information about deformation in the overriding plate, but it is unclear if such data vary systematically with convergent margin type. In order to assess the utility of the southern Oregon uplift rates for predicting the behavior of the Cascadia subduction zone, we compared late Quaternary uplift rates derived from terrace data from subduction zones around the world. On the basis of this comparison the southern Oregon rates of vertical deformation are not unusually high or low. Furthermore, late Quaternary uplift rates show little relationship to the type of convergent margin. These observations suggest that local structures may play a large role in uplift rate variability. In addition, while the type of convergent margin may place an upper limit on possible uplift rate, greater upper limits serve to increase the range of possible uplift rates. In the case of the southern Oregon coast, variability in uplift rate probably reflects local structures in the overriding plate, and the rate of uplift cannot be used as a simple index of the potential for great earthquakes along the southern Cascadia subduction zone.
\end{abstract}

\section{INTRODUCTION}

Slip between plates of the Cascadia subduction zone along the Pacific Northwest coast of the United States (Figure 1) may be capable of generating large earthquakes [Heaton and Kanamori, 1984; Heaton and Hartzell, 1986, 1987; Atwater, 1987; Spence, 1989]. In a comparison of physical characteristics, Heaton and Hartzell [1986] concluded that the Cascadia subduction zone is most like the seismically active "Chilean type" [Uyeda and Kanamori, 1979] in which young oceanic lithosphere is subducting and interplate coupling is strong. Other examples of this type occur in Colombia and southwestern Japan. Slip along such plate margins can result in major earthquakes, intense compression, and formation of folds or landward dipping imbricate thrust faults in the accretion complex.

Although the Cascadia subduction zone has many characteristics of the Chilean-type subduction zone, there are some differences [Spence, 1989], the most important being the absence of historic large earthquakes [Heaton and Hartzell, 1987]. Two possible interpretations of this absence are that subduction is occurring aseismically or that elastic strain is

\footnotetext{
${ }^{1}$ U.S. Geological Survey, Denver, Colorado.

${ }^{2}$ Department of Geology, Western Washington University, Bellingham.

${ }^{3}$ Center for Geochronological Research, Institute of Arctic and Alpine Research, University of Colorado, Boulder.

${ }^{4}$ Section of Invertebrate Paleontology, Los Angeles County Museum of Natural History, Los Angeles, California.
}

Copyright 1990 by the American Geophysical Union.

Paper number 89JB03531.

0148-0227/90/89JB-03531\$05.00 accumulating and may result in a large earthquake in the future. If the latter hypothesis is correct, estimates of the magnitude and recurrence interval of large earthquakes must rely on the Quaternary geologic record.

Geologic evidence of large earthquakes may be in the form of coseismically uplifted Holocene marine terraces. Holocene marine terraces of probable coseismic origin have been reported for subduction zones in central Chile, Japan, Alaska, Vanuatu, and New Zealand [Kaizuka et al., 1973; Matsuda et al., 1978; Plafker and Rubin, 1978; Taylor et al., 1980; Berryman et al., 1989]. However, along the Pacific Northwest coast adjacent to the Cascadia subduction zone, multiple Holocene terraces and/or beach ridges are found only near Cape Mendocino, California, which is near the triple junction of the Pacific, North American, and Gorda plates (Figure 1) [Lajoie et al., 1982]. Along the Oregon coast, only a single elevated Holocene beach berm of probable tectonic origin has been described [Kelsey, 1989]; no emergent Holocene shorelines have been reported on the outer Pacific coast of Washington.

Although most of the Pacific Northwest coast lacks flights of Holocene marine terraces, flights of Pleistocene marine terraces are well preserved. In this regard, Cascadia is similar to other subduction zones that lack or have scarce evidence of Holocene terraces but do show evidence of Pleistocene uplift. Such areas include north central Chile, parts of the Aleutian Islands, Timor and Atauro islands, and Barbados [Leonard et al., 1984; Szabo and Gard, 1975; Chappell and Veeh, 1978; Mesolella et al., 1969]. Although coseismic terrace uplift is certainly not limited to the Holocene, similarities of uranium series ages of corals associated with terraces from many of the world's coastlines 


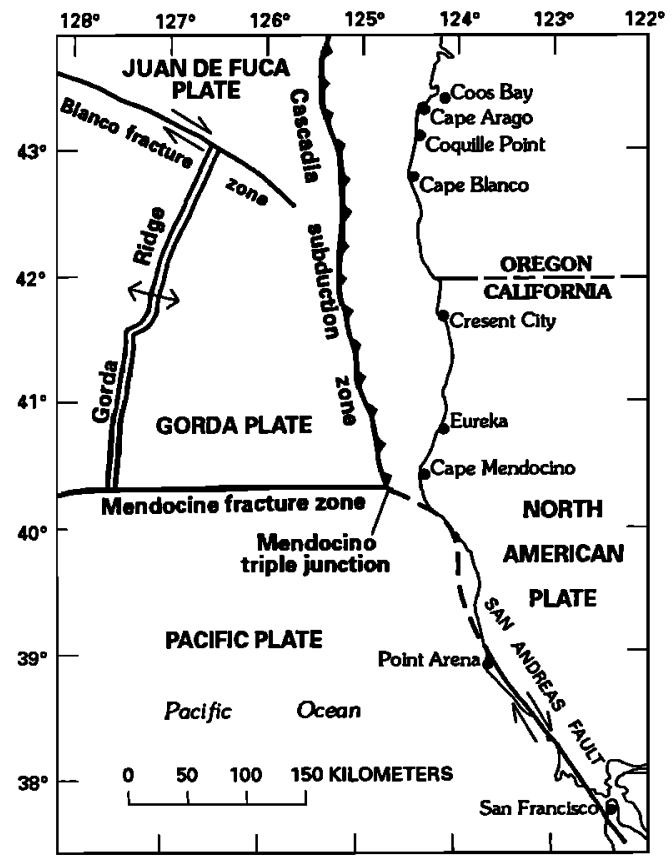

Fig. 1. Plate tectonic setting of southern Oregon and northern California, showing plate boundaries and study areas. Plate boundaries taken from Heaton and Hartzell [1987], McCulloch [1987], and Kelsey and Carver [1988].

indicate that flights of Pleistocene marine terraces are the result of terrace cutting or reef growth during Pleistocene sea level high stands that are superimposed on rising crustal blocks.

The most common method of estimating long-term uplift rates on a tectonically active coast utilizes accurate elevation measurements and dating of late Pleistocene marine terraces. Using this method, uplift rates along the southern Oregon coast have been estimated by Wehmiller et al. [1977], Adams [1984], and West and McCrumb [1988]. All of these workers necessarily made assumptions about terrace ages, terrace correlations, and position of sea level at the time of terrace formation. We present here new information that allows revision of uplift rates for this area.

This paper serves two purposes. First, we present new uranium series, amino acid, and stable isotope measurements that allow us to determine alternative ages and uplift rates of three terraces in southern Oregon. Second, we employ marine terrace uplift rates from southern coastal Oregon and from other convergent margins to test the hypothesis that rate of crustal uplift is a general indicator of the type of plate margin and the degree of plate interaction at a subduction zone. Uyeda and Kanamori [1979], Yonekura [1983], and Ota [1986] have suggested that uplift rate reflects the style of plate interaction at subduction zones. West and McCrumb [1988] placed considerable emphasis on their estimates of low uplift rate for Cascadia in contrast to apparent high long-term uplift rates for other subduction zones in explaining the lack of Cascadia earthquakes. Finally, we provide new ages of marine terraces that will allow better estimates of slip rates of faults that displace the terraces, the tilt rates, and the continued growth of local structures such as anticlines and synclines that deform the terraces [McInelly et al., 1989]. Such studies are reported in detail in companion papers by McInelly and Kelsey [this issue] and Kelsey [1990].

\section{Marine Terraces in Southern Oregon}

The most extensive and best preserved marine terraces along the southern Oregon coast are near Cape Arago, Bandon, and Cape Blanco (Figures 1 and 2). Griggs [1945] mapped four terraces near Cape Arago and Bandon, naming the lowest three terraces, in ascending order, the Whisky Run, Pioneer, and Seven Devils terraces. Janda [1969, also Field guide to Pleistocene sediments and landforms and soil development in the Cape Arago-Cape Blanco area of Coos and Curry counties, southern coastal Oregon, Friends of the Pleistocene, 1970, hereinafter referred to as unpublished guidebook, 1970] reported four terraces in the Cape Blanco area, correlating the lowest with the Pioneer terrace of Griggs [1945] and naming the higher three, in ascending order, the Silver Butte, Indian Creek, and Poverty Ridge terraces. He correlated his Indian Creek terrace at Cape Blanco with the Seven Devils terrace of Griggs [1945] thus implying that his Silver Butte terrace is intermediate in age between the Pioneer and Seven Devils terraces of Griggs [1945] at Cape Arago. Beaulieu and Hughes [1976] mapped the terraces at Cape Blanco and identified "middle," "upper," and "higher" marine terraces which they correlated with the Pioneer, Seven Devils, and "higher" terraces, respectively, of Griggs [1945]. Baldwin [1981], in contrast to Janda [1969, also unpublished guidebook, 1970] and Beaulieu and Hughes [1976], correlated the lowest broad terrace at Cape Blanco with the Whisky Run terrace at Cape Arago. Except for the lowest broad terrace at Cape Blanco, West and $M c$ Crumb [1988] correlated the lowest terrace segments all along the coast from Cape Blanco, Oregon, to La Push, Washington, with the Whisky Run terrace, apparently basing much of their correlation on amino acid and faunal data of Kennedy [1978] and Kennedy et al. [1982].

Remapping of the terraces at Cape Blanco by Kelsey [1990] has resulted in changes from previous correlations of Janda [1969, also unpublished guidebook, 1970] and mapping of Beaulieu and Hughes [1976]. The geologic data used to support these changes are part of a much larger study and are not described here except to note that the term "Cape Blanco terrace" is used to denote an areally limited, 0.5-1.0 $\mathrm{km}$ wide terrace on the westernmost part of Cape Blanco (Figure 2), characterized by 7-10 $\mathrm{m}$ thick terrace cover sediments and a distinctive shell-rich basal unit (U.S. Geological Survey (USGS) locality M1450, Los Angeles County Museum of Natural History (LACMNH) locality 2641) that was described by Addicott [1964] and Kennedy [1978]. Another fossil locality (USGS locality M1452) described by Addicott is present on the next highest terrace, based on new mapping by Kelsey [1990] and is referred to as the Pioneer terrace by Kelsey. This terrace is equivalent to the Pioneer terrace of R. J. Janda (unpublished guidebook, 1970) with the exclusion of the areally limited Cape Blanco terrace.

Geochronological studies in southern Oregon have yielded uncertain ages for some of the terraces. On the basis of amino acid (D/L leucine) ratios in fossil mollusks, Kennedy et al. [1982] correlated the Whisky Run terrace with the $\sim 80$ ka sea level high stand reported from a number of tectonically active coastlines. This correlation was supported by zoogeographic aspects of the terrace faunas. These same 

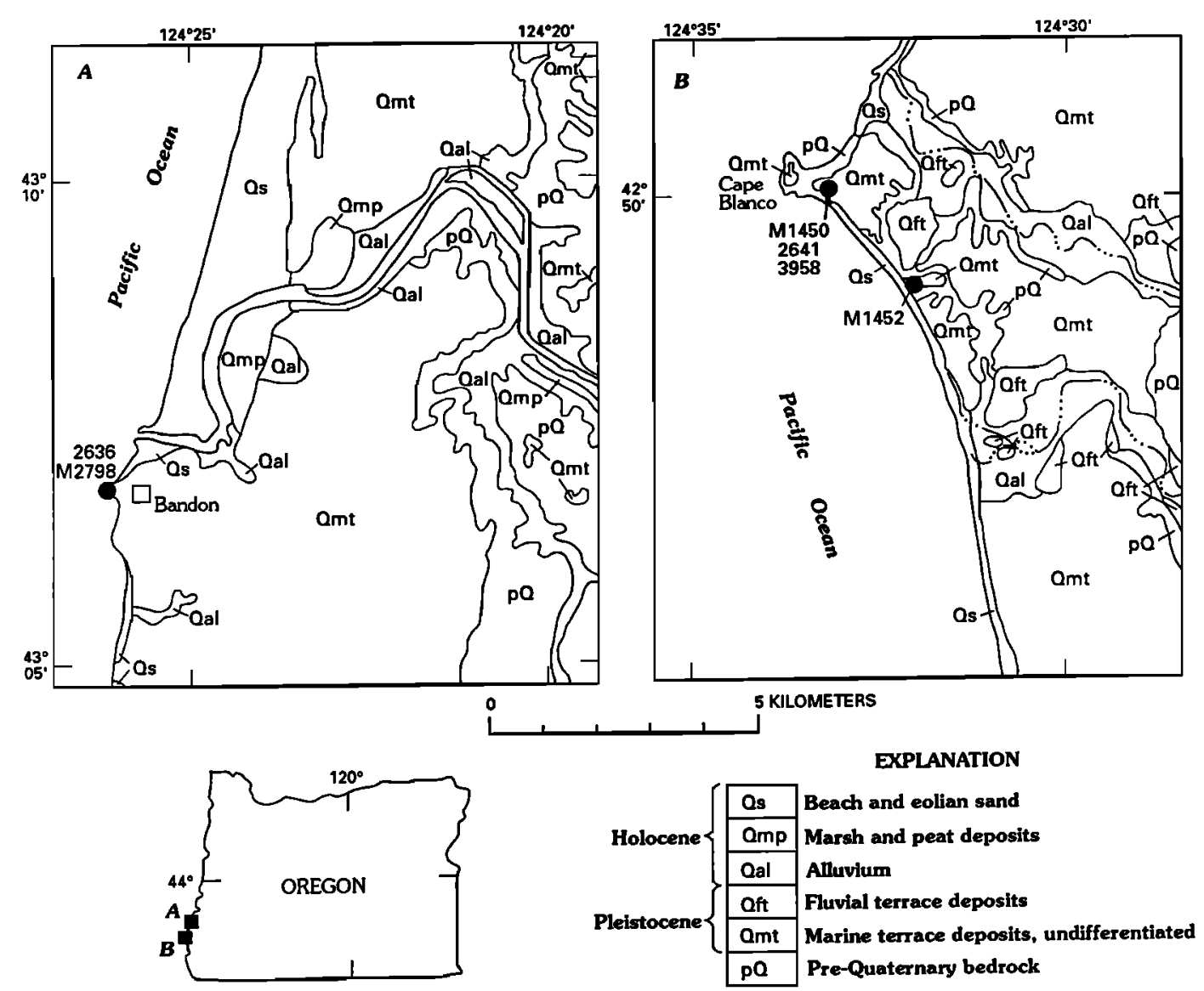

EXPLANATION

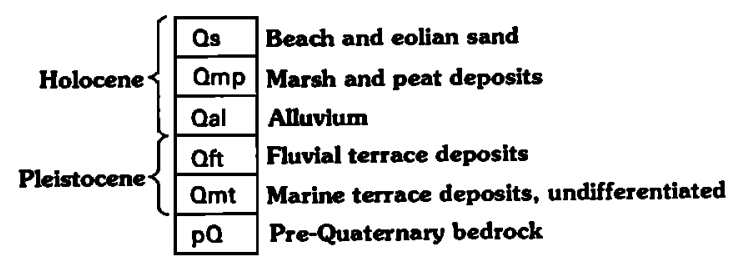

Fig. 2. Simplified Quaternary geologic maps of the (a) Coquille Point, Oregon and (b) Cape Blanco, Oregon, areas, showing fossil localities. Geology modified from Beaulieu and Hughes [1975, 1976].

workers reported a $U$ series age of $\sim 72$ ka for fossil coral found in the terrace deposits. They noted, however, that the ${ }^{231} \mathrm{~Pa} /{ }^{235} \mathrm{U}$ ratio in this coral was greater than 1.00 , which is discordant with the ${ }^{230} \mathrm{Th} /{ }^{234} \mathrm{U}$ age of $72 \mathrm{ka}$. Kennedy et al. [1982] also reported amino acid ratios in mollusks from what we call the Cape Blanco terrace that are lower than those in mollusks from the Whisky Run terrace at Coquille Point. Wehmiller et al. [1977] had previously used these amino acid ratios to suggest an age of 45-75 ka for the Cape Blanco terrace. Thus the amino acid data of Wehmiller et al. [1977] and Kennedy et al. [1982], in contrast to Janda [1969, also unpublished guidebook, 1970], imply that the Cape Blanco terrace is not only younger than the Pioneer terrace but also younger than the Whisky Run terrace. The 45-75 ka age estimate for the Cape Blanco terrace was used by Adams [1984] and West and McCrumb [1988]. Kennedy [1978] and Kennedy et al. [1982] noted, however, that the zoogeographic aspect of the Cape Blanco terrace fauna is similar to that from the Whiskey Run terrace, which suggests that these two terraces could be coeval. In southern California, for instance, terrace faunas that are correlated with 40-60 ka high sea stands on the basis of amino acid ratios have a significantly cooler water signature than do nearby terrace faunas that correlate with the 80 and 120 ka high sea stands [Kennedy et al., 1982; Kennedy and Wehmiller, 1986].

The various options for age estimates of terraces in southern Oregon have a significant effect on the determina- tion of late Quaternary uplift rates. For example, the Cape Blanco terrace has been correlated with the Pioneer terrace, the Whisky Run terrace, and with either of two possible post-Whisky Run high stands of sea level (see discussion above). As a result, estimates of possible uplift rate for this terrace range from about 0.65 to $2.75 \mathrm{~m} / \mathrm{kyr}$.

In order to resolve some of the problems of age estimates of southern Oregon terraces and their resultant uplift rates we have applied various dating and correlation techniques to corals, bryozoans, and mollusks from the Whisky Run terrace at Coquille Point and to bryozoans and mollusks from the Cape Blanco and Pioneer terraces at Cape Blanco. Corals suitable for uranium series age determinations were found only at Coquille Point. Bryozoans, not previously investigated for uranium series age determinations, are present in southern Oregon and northern California marine terrace deposits and were used for a uranium series dating feasibility study. Mollusks are not reliable for uranium series dating [Kaufman et al., 1971] but can yield oxygen isotope ratios and amino acid ratios that can be used in terrace correlation. In addition to the southern Oregon samples we generated new uranium series ages for corals, bryozoans, and sea urchins and amino acid ratios for mollusks from the lowest, 23-m, marine terrace at Point Arena, California [Kennedy, 1981] (Figure 1 and 3). The Point Arena terrace is the closest late Quaternary terrace with sufficient coral for $U$ series dating. 


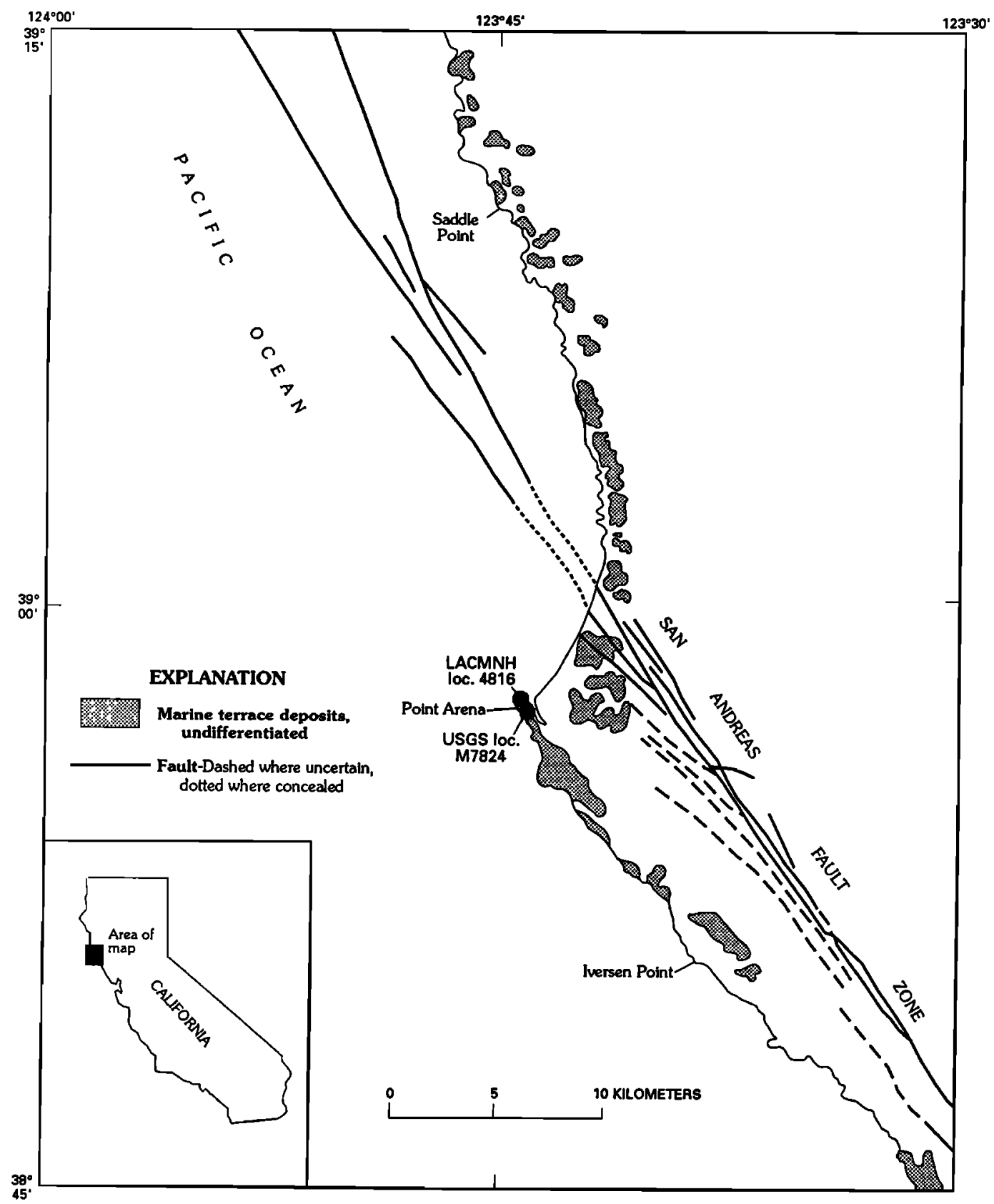

Fig. 3. Generalized map of marine terrace deposits, terrace fossil localities, and faults in the Point Arena, California, area. Geology and faults generalized from Jennings and Strand [1960], Wagner and Bortugno [1982], and McCulloch [1987].

\section{Uranium Series Dating}

Studies conducted over the last 30 years have demonstrated that unaltered, aragonitic coral is the most suitable material for ${ }^{230} \mathrm{Th} /{ }^{234} \mathrm{U}$ dating (see review by Veeh and Burnett [1982]). We analyzed newly collected specimens of the solitary coral Balanophyllia elegans Verrill from the Whisky Run terrace at Coquille Point and the lowest, 23-m terrace at Point Arena, California. We also analyzed bryozoans (Celleporina sp. and Heteropora sp.) from all three study areas to determine if they might be suitable for uranium series dating. Spines and plates of the sea urchin Strongylocentrotus are sometimes found in southern Oregon terrace deposits as well as at Point Arena and were also analyzed by the uranium series method.

Uranium and thorium concentrations and isotopic activity ratios in all samples were determined by isotope dilution alpha spectrometry. Samples were first cleaned mechanically by scraping and ultrasonic washing in distilled water. Mineralogy was determined by $\mathrm{X}$ ray diffraction analysis. Samples were then heated to $900^{\circ} \mathrm{C}$ for about 8 hours to destroy organic material and to convert $\mathrm{CaCO}_{3}$ to $\mathrm{CaO}$. Coral and sea urchin samples were then dissolved in $6 \mathrm{~N} \mathrm{HCl}$ and equilibrated with a combined ${ }^{229} \mathrm{Th}-{ }^{236} \mathrm{U}$ spike [Rosholt, 1984]. Bryozoans generally had large amounts of 
TABLE 1. Mineralogy, Uranium Concentrations, Isotopic Activity Ratios, and Calculated Ages of Corals, Bryozoans, and Sea Urchins From Oregon and California Marine Terraces

\begin{tabular}{|c|c|c|c|c|c|c|c|c|c|}
\hline \multirow[b]{2}{*}{ Location } & \multirow[b]{2}{*}{$\begin{array}{l}\text { Fossil } \\
\text { Locality }\end{array}$} & \multirow[b]{2}{*}{ Material $^{\mathfrak{a}}$} & \multirow[b]{2}{*}{ Mineralogy } & \multirow[b]{2}{*}{$\begin{array}{l}\text { U, } \\
\text { ppm }\end{array}$} & \multicolumn{3}{|c|}{ Activity Ratios } & \multirow{2}{*}{$\begin{array}{l}\text { Uncorrected } \\
\text { Age, } \\
\text { ka }\end{array}$} & \multirow{2}{*}{$\begin{array}{l}\text { Corrected } \\
\text { Age, }^{c} \\
\text { ka }\end{array}$} \\
\hline & & & & & ${ }^{234} \mathrm{U} /$ & ${ }^{230} \mathrm{Th} /$ & ${ }^{230} \mathrm{Th} /$ & & \\
\hline \multirow[t]{2}{*}{$\begin{array}{l}\text { Coquille Point, } \\
\text { Oregon } \\
\text { (Whisky } \\
\text { Run terrace) }\end{array}$} & \multirow[t]{2}{*}{$\begin{array}{l}\text { USGS loc. } \\
\text { M2798; } \\
\text { LACMNH } \\
\text { loc. } 2636\end{array}$} & $\begin{array}{l}\text { Coral } \\
\text { (B.e.) }\end{array}$ & $\begin{array}{l}\text { aragonite } \\
(100 \%)\end{array}$ & $4.90 \pm 0.06$ & $1.10 \pm 0.01$ & 249 & $0.54 \pm 0.02$ & $83 \pm 5$ & \\
\hline & & $\begin{array}{l}\text { Bryozoan } \\
\text { (C.sp.) }\end{array}$ & $\begin{array}{l}\text { low-Mg } \\
\text { calcite } \\
\left(3 \% \mathrm{MgCO}_{3}\right)\end{array}$ & $0.68 \pm 0.01$ & $1.22 \pm 0.01$ & 22 & $0.53 \pm 0.01$ & $80 \pm 2$ & \\
\hline \multirow[t]{3}{*}{$\begin{array}{l}\text { Cape Blanco, } \\
\text { Oregon } \\
\text { (Cape Blanco } \\
\text { terrace) }\end{array}$} & \multirow[t]{3}{*}{$\begin{array}{l}\text { USGS loc. } \\
\text { M1450; } \\
\text { LACMNH } \\
\text { loc. } 3958\end{array}$} & $\begin{array}{l}\text { Bryozoan } \\
\text { (C.sp.) }\end{array}$ & $\begin{array}{l}\text { low-Mg } \\
\text { calcite } \\
\left(<2 \% \mathrm{MgCO}_{3}\right)\end{array}$ & $2.58 \pm 0.03$ & $1.11 \pm 0.01$ & 342 & $0.12 \pm 0.01$ & $14 \pm 1$ & \\
\hline & & $\begin{array}{l}\text { Bryozoan } \\
\text { (C.sp.) }\end{array}$ & $\begin{array}{l}\text { low-Mg } \\
\text { calcite } \\
\left(<2 \% \mathrm{MgCO}_{3}\right)\end{array}$ & $2.51 \pm 0.03$ & $1.15 \pm 0.01$ & $>1000$ & $0.09 \pm 0.01$ & $10 \pm 1$ & \\
\hline & & $\begin{array}{l}\text { Bryozoan } \\
\text { (H.sp.) }\end{array}$ & $\begin{array}{l}\text { low-Mg } \\
\text { calcite } \\
\left(3 \% \mathrm{MgCO}_{3}\right)\end{array}$ & $0.64 \pm 0.01$ & $1.50 \pm 0.02$ & 29 & $1.50 \pm 0.02$ & $\cdots$ & \\
\hline \multirow[t]{4}{*}{$\begin{array}{l}\text { Point Arena, } \\
\text { California }\end{array}$} & \multirow[t]{4}{*}{$\begin{array}{l}\text { USGS loc. } \\
\text { M7824 }\end{array}$} & $\begin{array}{l}\text { Coral } \\
\text { (B.e.) }\end{array}$ & $\begin{array}{l}\text { aragonite } \\
(100 \%)\end{array}$ & $4.8 \pm 0.1$ & $1.12 \pm 0.02$ & 85 & $0.51 \pm 0.02$ & $76 \pm 4$ & \\
\hline & & $\begin{array}{l}\text { Bryozoan } \\
\text { (C. sp.) }\end{array}$ & $\begin{array}{l}\text { low-Mg } \\
\text { calcite }\end{array}$ & $0.79 \pm 0.01$ & $1.24 \pm 0.01$ & 29 & $0.52 \pm 0.01$ & $77 \pm 2$ & \multirow{3}{*}{$82 \pm 11$} \\
\hline & & $\begin{array}{l}\text { Urchin } \\
\text { plates }\end{array}$ & $\begin{array}{l}\left(7 \% \mathrm{MgCO}_{3}\right) \\
\text { low-Mg } \\
\text { calcite }\end{array}$ & $0.28 \pm 0.01$ & $1.15 \pm 0.03$ & 4.4 & $0.83 \pm 0.03$ & $176 \begin{array}{l}+20 \\
-17\end{array}$ & \\
\hline & & $\begin{array}{l}\text { (S. spp.) } \\
\text { Urchin } \\
\text { spines } \\
(S . \text { spp.) }\end{array}$ & $\begin{array}{l}\left(7 \% \mathrm{MgCO}_{3}\right) \\
\text { low-Mg } \\
\text { calcite } \\
\left(3 \% \mathrm{MgCO}_{3}\right)\end{array}$ & $0.19 \pm 0.01$ & $1.14 \pm 0.03$ & 3.7 & $0.93 \pm 0.04$ & $253 \begin{array}{l}+56 \\
-36\end{array}$ & \\
\hline
\end{tabular}

USGS, U.S. Geological Survey; LACMNH, Los Angeles County Museum of Natural History.

${ }^{a}$ B.e., Balanophyllia elegans Verrill, 1864; $S$. spp., Strongylocentrotus spp., probably mostly $S$. purpuratus (Stimpson, 1857), $C$. sp., Celleporina sp.; $\boldsymbol{H}$. sp., Heteropora sp.

${ }^{b}$ Calculated using half-lives of ${ }^{230} \mathrm{Th}$ and ${ }^{234} \mathrm{U}$ of 75,200 and 244,000 years, respectively.

${ }^{c}$ Corrected for inherited ${ }^{230} \mathrm{Th}$ using the graphical method of $S z a b o\left[1985\right.$, Figure 4]. Corrected ${ }^{230} \mathrm{Th} /{ }^{234} \mathrm{U}=0.54 \pm 0.04$ and corrected ${ }^{234} \mathrm{U} /{ }^{238} \mathrm{U}=1.2 \pm 0.1$.

clay and other detrital materials adhering to them that were difficult to remove by mechanical means. These samples were added incrementally to $0.25 \mathrm{~N} \mathrm{HNO}_{3}$ following the method of Szabo et al. [1989] in order to minimize leaching of $U$ and Th from the adhering detrital particles. Detrital particles were then separated by centrifugation, and the supernatant liquid was equilibrated with the spikes. For all samples, $U$ was separated from $T h$ by use of an anion exchange column in chloride form. The $U$ and Th separates were further purified by use of coprecipitation and ion exchange methods. Samples were plated onto stainless steel disks and counted in an alpha spectrometer. Errors of one standard deviation are given in the text and in Table 1 for isotopic activity ratios and calculated ages and are based on counting statistics.

Our calculated ages of $83 \pm 5$ ka for Balanophyllia from the Whisky Run terrace and $76 \pm 4$ ka for the low terrace at Point Arena are in agreement with one another, within analytical error (Table 1), and support the previous correlation of these terraces with an $\sim 80 \mathrm{ka}$ high sea stand [Kennedy, 1978; Kennedy et al., 1982]. We regard these ages as reliable because (1) $U$ concentrations are within the typical range reported for Balanophyllia [Ku and Kern, 1974; Rockwell et al., 1989], (2) ${ }^{234} \mathrm{U} /{ }^{238} \mathrm{U}$ ratios are consistent with $\sim 80 \mathrm{ka}$ ages, and (3) ${ }^{230} \mathrm{Th} /{ }^{232} \mathrm{Th}$ ratios are high $(>20)$, indicating no inherited ${ }^{230} \mathrm{Th}$ (Table 1 ). Coral from marine deposits on the coasts of Barbados, Haiti, New Guinea, Japan, the southeastern United States, southern Califomia, and northern Baja California, Mexico, also have given $U$ series ages of about 80 ka [Mesolella et al., 1969; Dodge et al., 1983; Bloom et al., 1974; Konishi et al., 1974; Szabo, 1985; Muhs et al., 1988; Rockwell et al., 1989] and correlate with the high stand in southern Oregon and northern California.

Uranium series analyses of fossil bryozoans yielded uncertain results (Table 1). All bryozoans that were analyzed have high ${ }^{230} \mathrm{Th} /{ }^{232} \mathrm{Th}$ ratios, indicating no inherited ${ }^{230} \mathrm{Th}$. With the exception of the Cape Blanco samples, all bryozoans have ${ }^{234} \mathrm{U} /{ }^{238} \mathrm{U}$ ratios significantly greater than 1.15 , which indicates that at least some of the $U$ in these fossils was continentally derived, rather than derived from marine waters. Fossil Heteropora yielded a ${ }^{230} \mathrm{Th} /{ }^{234} \mathrm{U}$ ratio in excess of 1.00 , indicating postdepositional $U$ loss. However, Celleporina from Coquille Point and Point Arena gave $U$ series ages of $\sim 80 \mathrm{ka}$, which agree with the $U$ series ages of Balanophyllia from these localities. Ages of about $80 \mathrm{ka}$ together with high ${ }^{234} \mathrm{U} /{ }^{238} \mathrm{U}$ ratios indicate a continentally derived source of $U$, but $U$ uptake by the bryozoans must have occurred soon after terrace emergence. These results initially suggested to us that Celleporina may be suitable for $\mathrm{U}$ series dating. However, Celleporina from the Cape Blanco terrace gave geologically unreasonable ages of $14 \pm$ 
TABLE 2. Ratios of D-Allo-Isoleucine to L-Isoleucine (alle/lle) and Stable Isotope Data for Fossil Mya Truncata

\begin{tabular}{|c|c|c|c|c|c|c|c|c|c|}
\hline Location & $\begin{array}{c}\text { MAT, }^{a} \\
{ }^{\circ} \mathrm{C}\end{array}$ & $\begin{array}{c}\text { Fossil } \\
\text { Locality }\end{array}$ & $\begin{array}{l}\text { Amino Acid } \\
\text { Laboratory } \\
\text { Number }^{b}\end{array}$ & alle/Ile & $\begin{array}{c}\text { Group } \\
\text { Mean } \\
\pm 1 \sigma\end{array}$ & $\delta_{\% 0}^{13} \mathrm{C}, \mathrm{PDB}$, & $\begin{array}{l}\text { Group } \\
\text { Mean, } \\
\pm 1 \sigma\end{array}$ & $\underset{\% \circ}{\delta^{18} \mathrm{O}, \mathrm{PDB}}$ & $\begin{array}{l}\text { Group } \\
\text { Mean, } \\
\pm 1 \sigma\end{array}$ \\
\hline $\begin{array}{l}\text { Coquille Point, } \\
\text { Oregon } \\
\text { (Whisky } \\
\text { Run } \\
\text { terrace) }\end{array}$ & 10.9 & $\begin{array}{l}\text { LACMNH } \\
\text { loc. 2636; } \\
\text { USGS loc. } \\
\text { M2798 }\end{array}$ & $\begin{array}{r}\text { AAL-5331-A } \\
-B \\
-C \\
-D \\
-E\end{array}$ & $\begin{array}{l}0.30 \\
0.28 \\
0.28 \\
0.30 \\
0.26\end{array}$ & $0.28 \pm 0.01$ & $\begin{array}{l}1.3 \\
1.1 \\
\cdots \\
\cdots \\
\cdots\end{array}$ & $1.2 \pm 0.1$ & $\begin{array}{l}3.0 \\
3.1 \\
\cdots \\
\cdots \\
\cdots\end{array}$ & $3.0 \pm 0.1$ \\
\hline $\begin{array}{l}\text { Cape Blanco, } \\
\text { Oregon } \\
\text { (Cape Blanco } \\
\text { terrace) }\end{array}$ & 10.2 & $\begin{array}{l}\text { LACMNH } \\
\text { loc. 2641; } \\
\text { USGS loc. } \\
\text { M1450 }\end{array}$ & $\begin{array}{r}\text { AAL-3016-A } \\
-B \\
\text { AAL-5471-A } \\
-B\end{array}$ & $\begin{array}{l}0.21 \\
0.20 \\
0.21 \\
0.23\end{array}$ & & $\begin{array}{l}\cdots \\
\cdots \\
1.2 \\
0.8\end{array}$ & & $\begin{array}{l}\cdots \\
\cdots \\
2.8 \\
2.7\end{array}$ & \\
\hline $\begin{array}{c}\text { Point Arena, } \\
\text { California }\end{array}$ & 11.8 & $\begin{array}{l}\text { LACMNH } \\
\text { loc. } 4816\end{array}$ & $\begin{array}{r}\text { AAL-5340-A } \\
-B\end{array}$ & $\begin{array}{l}0.32 \\
0.38\end{array}$ & $0.21 \pm 0.01$ & $\begin{array}{l}0.7 \\
\cdots \\
\cdots\end{array}$ & $0.9 \pm 0.2$ & $\begin{array}{l}2.8 \\
\cdots \\
\cdots\end{array}$ & $2.8 \pm 0.1$ \\
\hline
\end{tabular}

LACMNH, Los Ángeles County Museum of Natural History; USGS, U.S. Geological Survey. PDB is the Peedee belemnite standard.

${ }^{a}$ Mean annual air temperature. Data from National Climatic Center, Asheville, North Carolina. Periods of record: Point Arena, 1958-1986; Bandon (Coquille Point), 1950-1986; Cape Blanco, 1953-1977. ${ }^{b}$ Amino Acid Laboratory at the Center for Geochronological Research, Institute of Arctic and Alpine Research, University of Colorado,
Boulder, Colorado.

$1 \mathrm{ka}$ and $10 \pm 1 \mathrm{ka}$ (Table 1). Aminostratigraphic and oxygen isotope data (discussed below) cause us to reject these young ages. If they were correct, we would expect the mollusks from this terrace to yield very low amino acid ratios and an oxygen isotope composition that was highly enriched in ${ }^{18} \mathrm{O}$, neither of which is supported by our data. We conclude that Celleporina does not consistently yield reliable results for $\mathbf{U}$ series dating.

Urchin (Strongylocentrotus spp.) plates and spines from Point Arena contain inherited ${ }^{230} \mathrm{Th}$, as indicated by low ${ }^{230} \mathrm{Th}^{232} \mathrm{Th}$ ratios, and therefore yielded apparent ages that are much greater than the Balanophyllia age from this locality (Table 1). However, when these data are corrected for inherited ${ }^{230}$ Th using a two-point (i.e., for plates and spines) isochron method [Szabo, 1985], we obtain a reasonable age of $82 \pm 11$ ka. Although Muhs and Kennedy [1985] reported discouraging results for U series dating of Strongylocentrotus spp. from southern California, the results here suggest that future analyses of fossil urchin parts may still yield useable ages.

\section{Aminostratigraphy of Marine Terrace Mollusks}

Correlation of marine terraces is possible using aminostratigraphy, which is based on the extent of diagenetic change of amino acids in the protein of a fossil shell over its geologic life. Living organisms have amino acids that are almost exclusively of the $L$ configuration. However, upon death of an organism, the $L$ enantiomers begin to convert to the same amino acids of the $D$ configuration, a process called racemization. A similar process, called epimerization, transforms the amino acid L-isoleucine (Ile) to D-allo-isoleucine (alle). Both racemization and epimerization are reversible, first-order reactions that will tend toward an equilibrium $D / L$ ratio of about 1.00 (most amino acids) or 1.25-1.30 (alle//le). Only alle/Ile ratios are reported herein (Tables 2 and 3 ).

Epimerization and racemization rates vary with genus and thermal history. Older mollusks have higher alle/lle ratios than younger mollusks of the same genus if their integrated thermal histories are similar; similar ratios imply similar ages. In deposits of the same age but with differing thermal histories, alle/lle ratios will be higher where temperatures have been higher over the life of the sample. One of the more reliable genera of bivalve mollusks for aminostratigraphic purposes on the Pacific coast is Saxidomus [Wehmiller et al., 1977; Lajoie et al., 1980; Wehmiller, 1982]. Another bivalve that is found in fossiliferous marine terrace deposits in Oregon, and which has been used extensively in aminostratigraphic applications in the Arctic, is Mya truncata Linnaeus [Miller, 1985]. We analyzed Mya truncata from Coquille Point, Cape Blanco (Cape Blanco terrace only), and Point Arena and Saxidomus giganteus Deshayes from Coquille Point and Cape Blanco (both the Cape Blanco and Pioneer terraces). For determination of alle/Ile ratios, laboratory procedures followed those described by Miller [1985, preparation $\mathrm{A}]$.

For aminostratigraphic correlation, certain assumptions about temperature history are made. Present mean annual air temperatures (MAT) at Bandon (Coquille Point) and Cape Blanco are $10.9^{\circ}$ and $10.2^{\circ} \mathrm{C}$, respectively, whereas MAT at Point Arena is $11.8^{\circ} \mathrm{C}$ (Table 2). Cape Blanco is slightly cooler than Coquille Point probably because of its more exposed position on the coast. However, during most of late Quaternary time there was a significantly greater amount of global glacial ice than during the present, sea level was considerably lower, and the Oregon and California shorelines were several kilometers west of where they are now. Under such conditions both Cape Blanco and Coquille Point were inland locations, and it is likely that their temperature histories are similar. Point Arena, situated more than $300 \mathrm{~km}$ to the south of the Oregon localities, probably experienced higher temperatures than those sites farther north. Accordingly, alle/lle ratios in fossil Mya from Point Arena should be, and are, slightly higher than those from Coquille Point (Table 2) because the $U$ series ages indicate that these terraces are correlative.

Amino acid data for Saxidomus show no significant differences in mean alle/Ile ratios between the Whisky Run terrace at Coquille Point and the Cape Blanco and Pioneer 
TABLE 3. Ratios of D-Allo-Isoleucine to L-Isoleucine (aIle/Ile) and Stable Isotope Data for Fossil Saxidomus Giganteus

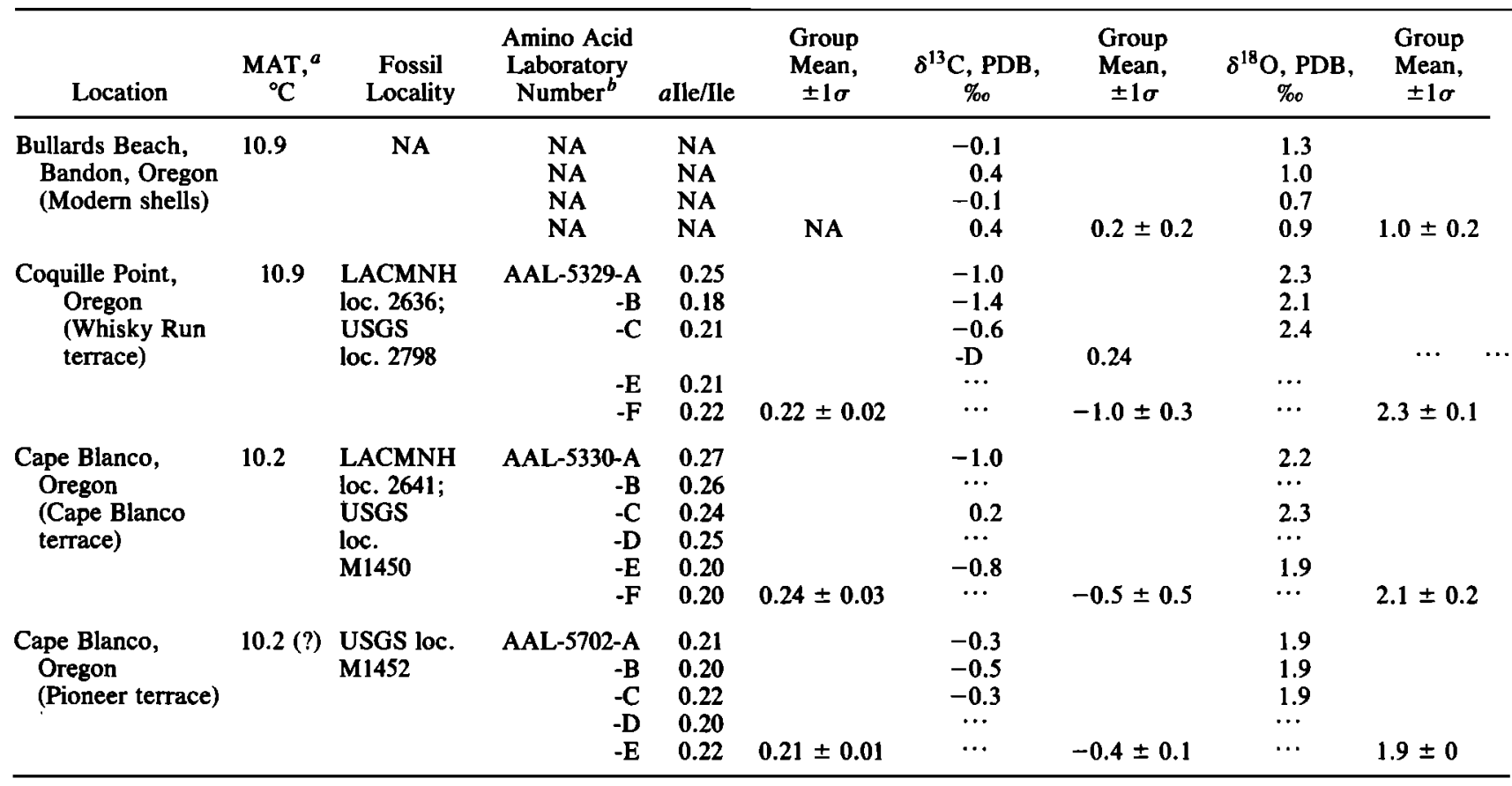

LACMNH, Los Angeles County Museum of Natural History; USGS, U.S. Geological Survey. PDB is the Peedee belemnite standard. ${ }^{a}$ Mean annual air temperature. Data from National Climatic Data Center, Asheville, North Carolina. Periods of record: Bandon (Coquille Point), 1950-1986; Cape Blanco, 1953-1977.

${ }^{b}$ Amino Acid Laboratory at the Center for Geochronological Research, Institute of Arctic and Alpine Research, University of Colorado, Boulder, Colorado.

terraces at Cape Blanco (Table 3). Similarity of alle/Ile ratios among all three terraces and the $\sim 80 \mathrm{ka}$ age for the Whisky Run terrace suggest two possible interpretations. The first interpretation is that the Pioneer terrace at Cape Blanco is correlative with the $\sim 80$ ka Whisky Run terrace at Coquille Point and the Cape Blanco terrace represents the $\sim 60 \mathrm{ka}$ high stand of sea reported from Barbados and New Guinea [James et al., 1971; Bloom et al., 1974]. However, this interpretation is not consistent with the similar zoogeographic aspect of the faunas from the Whisky Run terrace and the Cape Blanco terrace. If the Cape Blanco terrace is $\sim 60 \mathrm{ka}$, its fauna should show a cooler water signature than that from the $\sim 80 \mathrm{ka}$ Whisky Run terrace [Kennedy et al., 1982], which it does not. A second interpretation is that the Cape Blanco terrace is correlative with the 80 ka Whisky Run terrace at Coquille Point, and the higher Pioneer terrace is slightly older, perhaps correlative with the $\sim 105 \mathrm{ka}$ high stand of sea recorded on Barbados, Haiti, and New Guinea [Mesolella et al., 1969; Dodge et al., 1983; Bloom et al., 1974]. A correlation of the Pioneer terrace to the $105 \mathrm{ka} \mathrm{high}$ sea stand is reasonable because amino acid ratios may not have the resolving power necessary to distinguish shells that differ in age by only $\sim 25 \mathrm{kyr}$ (80 ka versus $105 \mathrm{ka}$ ), particularly if the intervening period was relatively cold. A $105 \mathrm{ka}$ age assignment is consistent with geologic and pedologic data presented by Kelsey [1990].

Amino acid data for Mya truncata do not allow a simple geologic interpretation of terrace ages (Table 2). The amino acid ratios ( $a$ Ile/Ile) in Mya from Coquille Point and Point Arena show a difference that would be expected for two coeval terrace deposits (based on the $\sim 80 \mathrm{ka} \mathrm{U}$ series ages of corals) in latitudinally separated locales, as discussed above.
However, amino acid ratios in Mya from the Cape Blanco terrace are significantly lower than amino acid ratios in $M y a$ from the $80 \mathrm{ka}$ Whisky Run terrace at Coquille Point. This would imply that the Cape Blanco terrace is significantly younger than $80 \mathrm{ka}$, as suggested by previous Saxidomus leucine data [Kennedy, 1978; Kennedy et al., 1982]. The Cape Blanco terrace might therefore be correlative with one of the $40-60 \mathrm{ka}$ terraces reported from Barbados, New Guinea, and Japan [James et al., 1971; Bloom et al., 1974; Konishi et al., 1974]. Such an interpretation conflicts with the terrace faunal data, however, which suggest no significant differences in thermal aspect between the Cape Blanco terrace and the Whisky run terrace at Coquille Point [Kennedy, 1978].

\section{OXYGEN ISOTOPE STRATIGRAPHY}

Because the $U$ series and amino acid data yielded an ambiguous age assignment for the Cape Blanco terrace, we analyzed terrace mollusks for oxygen isotope composition. The oxygen isotope composition of a mollusk shell at a given locality is a function of the oxygen isotope composition of the global ocean and of water temperature at the time of shell formation. Oxygen isotope studies of fossil mollusks and corals from Barbados, New Guinea, and California show that significant differences in isotopic composition of organisms from terraces of different ages exist and are useful for terrace correlation [Fairbanks and Matthews, 1978; Matthews, 1985; Aharon and Chappell, 1986; Muhs and Kyser, 1987].

Mollusks from 40-60 ka terraces in New Guinea have oxygen isotope values of -0.7 to $-0.8 \%$ (in delta notation, 
relative to Peedee belemnite standard (PDB)), whereas 80 105 ka terrace mollusks have values ranging from -1.3 to $-1.4 \%$ [Aharon and Chappell, 1986]. This difference probably reflects both lower ocean temperatures and greater global ice volumes at $40-60 \mathrm{ka}$ than at $80-105 \mathrm{ka}$. There is no significant difference in isotopic composition between $80 \mathrm{ka}$ and 105 ka shells from New Guinea [Aharon and Chappell, 1986]. Therefore, if the Whisky Run terrace fauna is $80 \mathrm{ka}$ and the Cape Blanco terrace fauna is $40-60 \mathrm{ka}$, we hypothesize that the Cape Blanco terrace shells should be at least $0.5-0.7 \%$ heavier than the Coquille Point shells. If the Cape Blanco terrace is $80 \mathrm{ka}$, we hypothesize no significant difference in oxygen isotope composition. In addition, if the Cape Blanco terrace is $\mathbf{8 0} \mathbf{~ k a}$ and the higher Pioneer terrace at Cape Blanco is $105 \mathrm{ka}$, we would expect no significant difference in oxygen isotopic composition of Pioneer terrace shells and Cape Blanco terrace shells. Methods of stable isotope analysis followed those of Aharon and Chappell [1986] and Muhs and Kyser [1987]. Prior to analysis, all shells were mechanically cleaned. Radial slices were taken across the growth layers in order to average out seasonal effects. All shells studied were $99-100 \%$ aragonite, as determined by $X$ ray diffraction analysis. Oxygen and carbon isotopic composition was determined by mass spectrometry and is reported in delta notation, relative to PDB (Tables 2 and 3).

A comparison of the oxygen isotope values for modern Saxidomus shells collected at Bandon (Bullards Beach State Park) with those from the Whisky Run terrace at Bandon indicates that water temperatures off Bandon at $80 \mathrm{ka}$ were significantly cooler than they are today (Table 3 ). Modern Bandon shells are about $1.3 \%$ lighter than $80 \mathrm{ka}$ shells; this difference is slightly greater than the difference between modern and $80 \mathrm{ka}$ shells in southern California [Muhs and Kyser, 1987]. Depending on which estimate of the position of sea level at $80 \mathrm{ka}$ one uses (see discussion below), the data indicate water temperature reductions of $4.7^{\circ}-5.4^{\circ} \mathrm{C}$ off the Oregon coast, relative to present, at $80 \mathrm{ka}$.

Our oxygen isotope data for Saxidomus and Mya indicate no significant difference between the Whisky Run and Cape Blanco terrace shells (Tables 2 and 3). These data therefore support the correlation of the Cape Blanco terrace with the $\sim 80 \mathrm{ka}$ high stand of sea. An unexpected result is that the mean value for Saxidomus shells from the Pioneer terrace (at USGS locality M1452) at Cape Blanco is about $0.4 \%$ lighter than the mean value for Saxidomus shells from the $\sim 80 \mathrm{ka}$ Whisky Run terrace (Table 3). We note, however, that oxygen isotope values for shells from the Pioneer terrace are not significantly different from those in shells from the Cape Blanco terrace. The combination of topographic position and amino acid data indicated to us earlier that the Pioneer terrace might be correlative with the $\sim 105 \mathrm{ka}$ high stand of sea. Oxygen isotope data from shells and corals from New Guinea and Barbados indicate no significant difference between the 80 and 105 ka high sea stands [Matthews, 1985; Aharon and Chappell, 1986], but data from New Guinea, Barbados, and California all indicate about a $0.3 \%$ difference between 80 and $125 \mathrm{ka}$ shells [Matthews, 1985; Aharon and Chappell, 1986; Muhs and Kyser, 1987]. Thus our oxygen isotope data could be used to infer a correlation of the Pioneer terrace with either the 105 or $125 \mathrm{ka}$ high stands of sea. However, as discussed earlier, geologic and pedologic data of Kelsey [1990] as well as the amino acid data pre- sented earlier argue against a correlation to the $125 \mathrm{ka}$ high stand. We conclude that the Pioneer terrace at Cape Blanco most probably represents the $105 \mathrm{ka}$ high stand of sea.

\section{LATE QUATERNARY UPLIFT RATES}

West and McCrumb [1988] inferred that the lowest terrace everywhere along the Oregon and Washington coast was the 80 ka Whisky Run terrace, except at Cape Blanco, where they assumed a 40-60 ka age [Kennedy et al., 1982] for the lowest terrace (i.e., our Cape Blanco terrace). West and McCrumb [1988] calculated uplift rates at Cape Blanco assuming that the $121-\mathrm{m}$ terrace there was correlative with the Whisky Run terrace. They also assumed a paleo-sea level of $-12 \mathrm{~m}$ relative to present at $80 \mathrm{ka}$ [Bloom et al., 1974]. In this paper we present alternative estimates of terrace age, position of sea level, and amount of tectonic uplift and calculate new uplift rate estimates.

To calculate the maximum possible late Quaternary uplift rate, we must know the age of the terrace, the highest elevation of the wave-cut platform at present, and the position of sea level (with respect to present) at the time of terrace formation. The highest elevation of the wave-cut platform is usually the shoreline angle (junction of the wave-cut platform and the sea cliff) and is the closest approximation to mean sea level at the time of terrace formation. However, in the case of landward tilted terraces such as those in Oregon the height of the shoreline angle, relative to the rest of the wave-cut platform, may have been reduced by landward tilt. This introduces uncertainties in uplift rate calculations that are not normally considered when terraces are untilted. On a landward tilted terrace, parts of the platform that were originally some distance offshore either did not form at the same sea level as the shoreline angle or formed in deeper water when the shoreline angle was being cut [Bradley and Griggs, 1976]. It should be possible to correct for this using modern shore platform gradients, but there are few data available. The closest area for which there are good data is the central California coast, where modern platforms have inner segments that slope $15-40 \mathrm{~m} / \mathrm{km}\left(0.9^{\circ}-2.3^{\circ}\right)$ and outer segments that slope 5-17 $\mathrm{m} / \mathrm{km}\left(0.3^{\circ}-1.0^{\circ}\right)$ [Bradley and Griggs, 1976].

We estimate the amount of elevation change due to tectonic tilting using the highest elevations of the platforms at present and reasonable assumptions about original terrace gradients. The highest platform elevation of the Pioneer terrace at Cape Blanco is about $57 \mathrm{~m}$ at a point that is about $5.3 \mathrm{~km}$ seaward of the shoreline angle of that terrace. The Whisky Run terrace at Coquille Point has platform elevations at the outer edge and at the shoreline angle that do not differ significantly $(17 \mathrm{~m}$ versus $20 \mathrm{~m}$ ); the distance between these two points is approximately $2.8 \mathrm{~km}$. Because inner platform segments in central California are usually about 300-600 m wide [Bradley and Griggs, 1976], its seems more appropriate to use the gentler, outer platform gradients (5-17 $\mathrm{m} / \mathrm{km}$ ) for the relatively broad Pioneer and Whisky Run terraces. In contrast, the Cape Blanco terrace's outer edge has a maximum elevation of $\sim 53 \mathrm{~m}$ and is only $0.7 \mathrm{~km}$ from the shoreline angle of that terrace. Hence it is more appropriate to use the steeper inner segment gradients (15-40 $\mathrm{m} / \mathrm{km}$ ) for this terrace. For all terraces we calculated upper and lower limits of uplift using the endpoint elevations obtained from the ranges of platform gradients (Table 4). 
TABLE 4. Late Quaternary Uplift Rates Derived From Marine Terrace Data

\begin{tabular}{|c|c|c|c|c|c|c|c|c|}
\hline $\begin{array}{c}\text { Terrace, } \\
\text { Age, }^{a} \\
\text { ka }\end{array}$ & $\begin{array}{c}\text { Present } \\
\text { Elevation, } \\
\text { m }\end{array}$ & $\begin{array}{c}\text { Shore- } \\
\text { Normal } \\
\text { Distance } \\
\text { From } \\
\text { Shoreline } \\
\text { Angle, }{ }^{c} \\
\text { km }\end{array}$ & $\begin{array}{c}\text { Original } \\
\text { Gradient } \\
\text { of } \\
\text { Platform, } \\
\text { m/km }\end{array}$ & $\begin{array}{c}\text { Original } \\
\text { Depth of } \\
\text { Platform, } \\
\text { m }\end{array}$ & $\begin{array}{c}\text { Paleo- } \\
\text { Sea } \\
\text { Level, }^{f} \\
\text { m }\end{array}$ & $\begin{array}{c}\text { Sea } \\
\text { Level } \\
\text { Model }^{g}\end{array}$ & $\begin{array}{l}\text { Tectonic } \\
\text { Uplift, }{ }^{h} \mathrm{~m}\end{array}$ & $\begin{array}{c}\text { Uplift } \\
\text { Rate, } \\
\text { m/kyr }\end{array}$ \\
\hline \multicolumn{9}{|c|}{ Coquille Point, Oregon } \\
\hline WR, 80 & 17 & 2.8 & 5 & 14 & $-19 \pm 5$ & NG & $50 \pm 5$ & $0.62 \pm 0.07$ \\
\hline WR, 80 & 17 & 2.8 & 17 & 48 & $-19 \pm 5$ & NG & $84 \pm 5$ & $1.05 \pm 0.06$ \\
\hline WR, 80 & 17 & 2.8 & 5 & 14 & $-5 \pm 2$ & C-J & $36 \pm 2$ & $0.45 \pm 0.03$ \\
\hline WR, 80 & 17 & 2.8 & 17 & 48 & $-5 \pm 2$ & C-J & $70 \pm 2$ & $0.88 \pm 0.03$ \\
\hline \multicolumn{9}{|c|}{ Cape Blanco, Oregon } \\
\hline $\mathrm{CB}, 80$ & 53 & 0.7 & 15 & 10 & $-19 \pm 5$ & NG & $82 \pm 5$ & $1.02 \pm 0.07$ \\
\hline $\mathrm{CB}, 80$ & 53 & 0.7 & 40 & 28 & $-19 \pm 5$ & NG & $100 \pm 5$ & $1.25 \pm 0.06$ \\
\hline $\mathrm{CB}, 80$ & 53 & 0.7 & 15 & 10 & $-5 \pm 2$ & C-J & $68 \pm 2$ & $0.85 \pm 0.03$ \\
\hline $\mathrm{CB}, 80$ & 53 & 0.7 & 40 & 28 & $-5 \pm 2$ & C-J & $86 \pm 2$ & $1.08 \pm 0.03$ \\
\hline$P, 105$ & 57 & 5.3 & 5 & 26 & $-9 \pm 3$ & NG & $92 \pm 3$ & $0.88 \pm 0.03$ \\
\hline$P, 105$ & 57 & 5.3 & 17 & 90 & $-9 \pm 3$ & NG & $156 \pm 3$ & $1.49 \pm 0.03$ \\
\hline$P, 105$ & 57 & 5.3 & 5 & 26 & -2 & C-J & 85 & 0.81 \\
\hline $\mathrm{P}, 105$ & 57 & 5.3 & 17 & 90 & -2 & C-J & 149 & 1.42 \\
\hline \multicolumn{9}{|c|}{ Point Arena, California } \\
\hline 80 & 23 & $\mathbf{0}$ & NA & 0 & $-19 \pm 5$ & NG & $42 \pm 5$ & $0.52 \pm 0.07$ \\
\hline 80 & 23 & 0 & NA & 0 & $-5 \pm 2$ & C-J & $28 \pm 2$ & $0.35 \pm 0.03$ \\
\hline
\end{tabular}

${ }^{a}$ Terrace abbreviations: WR, Whisky Run; CB, Cape Blanco; P, Pioneer.

${ }^{b}$ For Cape Blanco and Coquille Point, elevations given are the highest field-surveyed elevations of wave-cut platforms on landward tilted terraces. For Point Arena the elevation given is the field-surveyed elevation of the shoreline angle.

${ }^{c}$ Horizontal distance from highest point of elevation on the platform to the shoreline angle.

${ }^{d}$ Gradients taken from Bradley and Griggs [1976].

e Depth below sea level at the time of terrace formation.

$f_{\text {Relative to present sea level. }}$

${ }^{g}$ New Guinea model (NG) from Chappell and Shackleton [1986]; California-Japan (C-J) model from Machida [1975], Muhs et al. [1988], and Rockwell et al. [1989].

${ }^{h}$ Uncertainties given are from paleo-sea level uncertainties.

New estimates of rate of uplift for the Coquille Point, Cape Blanco, and Point Arena areas are based on age assignments, elevations and gradients of wave-cut platforms, and two alternative estimates of the position of sea level at $\mathbf{8 0}$ and $105 \mathrm{ka}$ (Table 4). A widely accepted sea level curve for the late Quaternary is that derived from uplifted coral reefs on New Guinea [Bloom et al., 1974]. The latest revisions of this curve [Chappell and Shackleton, 1986] indicate a sea level of $-19 \pm 5 \mathrm{~m}$ at $\sim 80 \mathrm{ka}$ and $-9 \pm 3 \mathrm{~m}$ at $\sim 105 \mathrm{ka}$. In contrast, data from southern California, northern Baja California, Mexico, and Japan suggest that sea level was $-5 \pm$ $2 \mathrm{~m}$ at $\sim 80 \mathrm{ka}$ and about $-2 \mathrm{~m}$ at $105 \mathrm{ka}$ [Muhs et al., 1988; Rockwell et al., 1989; Machida, 1975]. We present calculated uplift rates using these two alternative estimates of the position of sea level (referred to as the "New Guinea" and "California-Japan" models, respectively, in Table 4) at the time of terrace formation.

On the basis of our new data the highest uplift rate on the southern Oregon coast is still that derived for the Cape Blanco area and has an estimated range of $0.81-1.49 \mathrm{~m} / \mathrm{kyr}$ (Table 4). However, some of our uplift rate estimates for this area are significantly lower than those reported by Wehmiller et al. [1977] and West and McCrumb [1988]. The uplift rates estimated by these previous investigators are higher than most of our estimates mainly because they inferred the Cape Blanco terrace to be $40-60 \mathrm{ka}$. The Coquille Point area has uplift rate estimates that range from 0.45 to $1.05 \mathrm{~m} / \mathrm{kyr}$ and are thus lower than those for Cape Blanco. Point Arena,
California, is adjacent to the San Andreas transform fault plate boundary (Figures 1 and 3), and the uplift rate estimates of $0.35-0.52 \mathrm{~m} / \mathrm{kyr}$ for this area are only slightly greater than those reported for similar tectonic settings in southern California [Ku and Kern, 1974; Kern, 1977; Muhs and Szabo, 1982; Muhs et al., 1987]. The range of possible uplift rates for terraces at Cape Blanco and Coquille Point illustrates how sensitive uplift rate calculations are to assumed values for paleo-sea level and platform gradient (Table 4). At Coquille Point, for example, uplift rate estimates vary by more than a factor of 2 .

\section{TYPES OF CONVERgENT MARgINS AND UPLIFT RATES: IS THERE A RELATIONSHIP?}

Uyeda and Kanamori [1979] proposed that uplift of coastal terraces along subduction zones has the same mechanism as the larger-scale compression and uplift of the accretionary prism. These investigators suggested that such compression and uplift would be most dramatic along "Chilean type" subduction zones where plate coupling is strongest and least dramatic along "Marianas type" subduction zones where plate coupling is weakest. Yonekura [1983] suggested that terrace uplift rates around the Pacific rim are a function of the degree of plate interaction. He proposed that uplift rates should vary as follows: little or nor uplift at intraplate locations (oceanic islands or atolls), low uplift rates on ocean-to-ocean subduction zones (island arcs), 
TABLE 5. Uplift Rates of 125 ka Terraces Near Subduction Zones

\begin{tabular}{|c|c|c|c|c|c|}
\hline Location and Abbreviation ${ }^{a}$ & $\begin{array}{l}\text { Elevation, } \\
\quad \mathrm{m}\end{array}$ & Dating Method & $\begin{array}{l}\text { Uplift } \\
\text { Rate, } \\
\text { m/kyr }\end{array}$ & $\underset{\text { sClass }}{\text { Strain }}$ & Reference \\
\hline \multicolumn{6}{|l|}{ Vanuatu } \\
\hline Torres Islands (TI) & 99 & U series, coral & 0.74 & 1 & Taylor et al. [1985] \\
\hline Erromango Island (EI) & 87 & U series, coral & 0.65 & 1 & Neef and Hendy [1988] \\
\hline Efate Island (EF) & 100 & U series, coral & 0.75 & 1 & $\begin{array}{l}\text { Lecolle and Bernat }[1985] \text { and } \\
\text { Neef and Veeh }[1977]\end{array}$ \\
\hline Malo Island (MA) & 96 & U series, coral & 0.72 & 1 & Neef and Veeh [1977] \\
\hline Malekula Island (MI) & $60^{d}$ & U series, coral & $\begin{array}{l}0.99^{e} \\
0.81^{f}\end{array}$ & 1 & Jouannic et al. [1980] \\
\hline \multicolumn{6}{|l|}{ Japan } \\
\hline South Kanto District (SK) & 160 & fission track, ash & 1.23 & 5 & $\begin{array}{l}\text { Ota [1985], Matsuda et al. [1978], } \\
\text { and Machida [1975] }\end{array}$ \\
\hline Noto Peninsula (NP) & 110 & U series, coral & 0.83 & 5 & $\begin{array}{l}\text { Omura }[1980] \text { and Ota and } \\
\text { Hirakawa }[1979]\end{array}$ \\
\hline Kikai Island (KI) & 224 & U series, coral & 1.74 & 2 & $\begin{array}{l}\text { Omura [1980] } \\
\quad \text { and Konishi et al. }[1974]\end{array}$ \\
\hline Hateruma Island (HI) & 41 & U series, coral & 0.28 & 2 & $\begin{array}{l}\text { Ota and Hori }[1980], \\
\text { Ota et al. }[1982], \\
\text { Konishi }[1980], \text { and } \\
\text { Omura }[1983,1984]\end{array}$ \\
\hline \multicolumn{6}{|l|}{ Indonesia } \\
\hline Timor (TM) & $26^{d}$ & U series, coral & $\begin{array}{l}0.56^{e} \\
0.39^{f}\end{array}$ & 5 & Chappell and Veeh [1978] \\
\hline $\begin{array}{l}\text { Atauro Island (AI) } \\
\text { Semau Island (SI) }\end{array}$ & $\begin{array}{r}63 \\
7\end{array}$ & $\begin{array}{l}\text { U series, coral } \\
\text { U series, coral }\end{array}$ & $\begin{array}{l}0.46 \\
0\end{array}$ & $\begin{array}{l}5 \\
5\end{array}$ & $\begin{array}{l}\text { Chappell and Veeh [1978] } \\
\text { Jouannic et al. }[1988]\end{array}$ \\
\hline New Guinea (NG) & 330 & U series, coral & 2.59 & $\cdots$ & $\begin{array}{l}\text { Bloom et al. }[1974], \\
\text { Chappell [1974], and } \\
\text { Veeh and Chappell [1970] }\end{array}$ \\
\hline \multicolumn{6}{|r|}{ 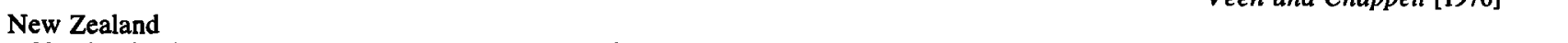 } \\
\hline North Island, east coast & 284 & fission track, ash & 2.22 & 3 & $\begin{array}{l}\text { Iso et al. [1982] and } \\
\quad \text { Yoshikawa et al. [1980] }\end{array}$ \\
\hline $\begin{array}{l}\text { North Island, west coast } \\
\text { (BP and TC, respectively) }\end{array}$ & 68 & $\begin{array}{l}\text { fission track, ash; } \\
\text { amino acids, wood }\end{array}$ & 0.50 & 3 & Pillans [1983] \\
\hline \multicolumn{6}{|l|}{ Tonga } \\
\hline Tongatapu Island (TO) & 6 & U series, coral & $\mathbf{0}$ & 1 & Taylor and Bloom [1977] \\
\hline Eua Island (EU) & 6 & U series, coral & 0 & 1 & Taylor and Bloom [1977] \\
\hline \multicolumn{6}{|l|}{ South America } \\
\hline North central Chile $(\mathrm{CH})$ & 20 & amino acids, shell & 0.11 & 7 & Leonard et al. [1984] \\
\hline South central Peru (PE) & 30 & amino acids, shell & 0.19 & 6 & Hsu et al. [1987] \\
\hline $\begin{array}{l}\text { South central Peru, } \\
\text { near Nazca Ridge (NA) }\end{array}$ & 110 & amino acids, shell & 0.83 & 6 & Hsu et al. [1987] \\
\hline Barbados (B) & 61 & U series, coral & 0.44 & 4 & $\begin{array}{l}\text { Mesolella et al. }[1969] \text { and } \\
\text { Bender et al. }[1979]\end{array}$ \\
\hline Aleutians (A) & 49 & U series, bone ${ }^{8}$ & 0.34 & 4 & Szabo and Gard [1975] \\
\hline \multicolumn{6}{|l|}{ Iran } \\
\hline Konarak (K) & 16 & U series, shell ${ }^{g}$ & 0.13 & $\cdots$ & Page et al. [1979] \\
\hline Jask (J) & 6 & U series, shell ${ }^{8}$ & 0 & $\cdots$ & Page et al. [1979] \\
\hline \multicolumn{6}{|l|}{ Oregon } \\
\hline Cape Blanco (CB) & $53^{d}$ & amino acids, shell & $\begin{array}{l}1.02- \\
1.25^{e} \\
0.85^{-} \\
1.08^{f}\end{array}$ & 4 & this study \\
\hline Coquille Point (CP) & $17^{d}$ & U series, coral & $\begin{array}{l}0.62- \\
1.05^{e} \\
0.45- \\
0.88^{f}\end{array}$ & 4 & this study \\
\hline
\end{tabular}

\footnotetext{
${ }^{a}$ See Figures 4 and 5.

${ }^{b}$ Present elevation of shoreline angle, highest platform elevation, or reef crest with respect to sea level.

c After Jarrard [1986].

${ }^{d}$ Terrace representing $125 \mathrm{ka}$ high stand of sea is undated; elevation given is for dated, $80 \mathrm{ka}$ terrace.

eUplift rate for dated 80 ka terrace based on New Guinea sea level model (see Table 4).

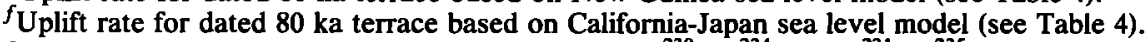

${ }^{8}$ Dated material is bone or shell but has concordant ${ }^{230} \mathrm{Th} /{ }^{234} \mathrm{U}$ and ${ }^{231} \mathrm{~Pa} /{ }^{235} \mathrm{U}$ ages.
} 


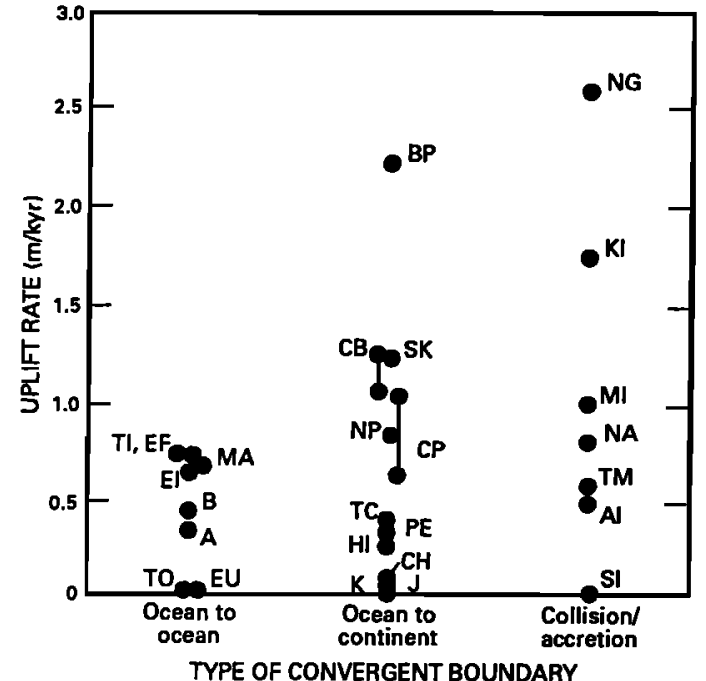

Fig. 4. Late Quaternary uplift rates of terraces near subduction zones shown as a function of type of convergent boundary. Convergent boundary types are those of Yonekura [1983]. Uplift rates and key to abbreviations given in Table 5 .

moderate and high uplift rates on ocean-to-continent subduction zones (continental arcs), and very high uplift rates on accretion or collision zones where relatively buoyant crust (such as aseismic ridges, seamounts, or other topographic highs) on the lower plate collides with a buoyant continental upper plate.

We tested the hypotheses of Uyeda and Kanamori [1979] and Yonekura [1983] by compiling late Quaternary uplift rates from marine terraces along various subduction zones and by comparing them to our new data for southern coastal Oregon (Table 5). In compiling these data we accepted only those areas for which there are unambiguous $U$ series, amino acid, or fission track ages for the terrace representing the peak of the last interglacial period $(\sim 125 \mathrm{ka})$, when sea level was about $6 \mathrm{~m}$ higher than present. In two areas we accepted $\mathrm{U}$ series ages of bone and shell because these materials yielded concordant ${ }^{230} \mathrm{Th} /{ }^{234} \mathrm{U}$ and ${ }^{231} \mathrm{~Pa} /{ }^{235} \mathrm{U}$ ages. We tried to limit our uplift rate estimates to terraces representing the $125 \mathrm{ka}$ high sea stand because it is the only late Pleistocene sea stand for which there is widespread agreement on the magnitude of sea level rise (see summaries by Bloom et al. [1974] and Chappell and Veeh [1978]). In a few areas, including southern Oregon, what is probably the 125 ka terrace has not been dated directly, but an 80 ka terrace has good age control. For these localities we present uplift rates using both the New Guinea and the California-Japan estimates of sea level position at $80 \mathrm{ka}$. In Figure 4, we have plotted these uplift rates as a function of the type of plate boundary as defined by Yonekura [1983]. In order to investigate further whether late Pleistocene uplift rates vary systematically along a spectrum of convergent margin types, we utilized a convergent margin classification of Jarrard [1986]. Jarrard identified seven strain classes of subduction zones. The strain classification is appropriate to our study because the focus of classification is on strain in the overriding plate. The strain classes range from extensional, with active back arc spreading (class 1) to strongly compressional (class 7). The "Marianas" and "Chilean" subduction zone types of Uyeda and Kanamori [1979] are the end-members

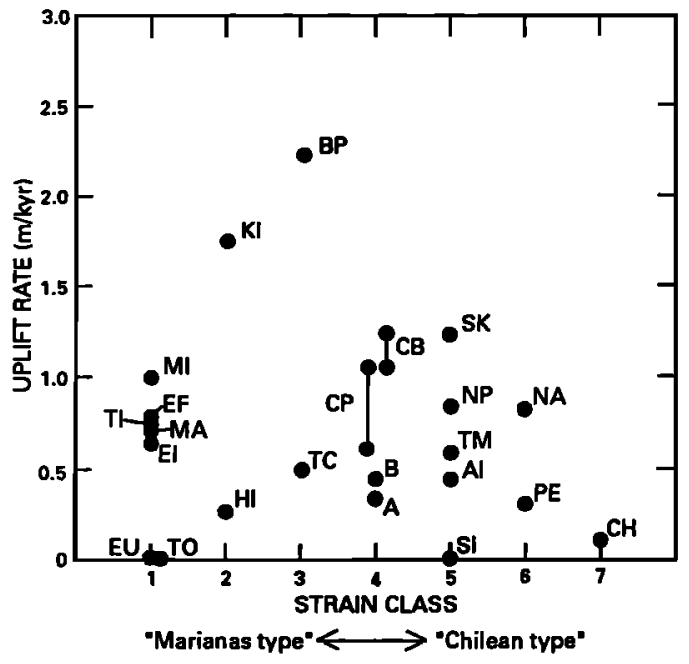

Fig. 5. Late Quaternary uplift rates of terraces near subduction zones shown as a function of strain class in the overriding plate. Strain classes are from Jarrard [1986]. Uplift rates and abbreviations are given in Table 5 . The different classes are plotted with equal spacings for clarity of presentation only, and the classes do not necessarily constitute equally spaced points along a strain continuum [Jarrard, 1986]. Three marine terrace localities (NG, K, and J) shown in Figure 4 are omitted here because strain class is uncertain or indeterminate.

(classes 1 and 7, respectively) of Jarrard's strain classes. Jarrard does not suggest that the classification should predict magnitude of marine terrace uplift. However, if Uyeda and Kanamori's [1979] hypothesis (see above) is correct, class 1 subduction zones should have low uplift rates and class 7 subduction zones should have high uplift rates, with classes 2-6 having intermediate rates. For simplicity, we have plotted only the maximum estimates of uplift rate (using the New Guinea sea level estimates for $80 \mathrm{ka}$ terraces) in Figures 4 and 5.

Late Quaternary uplift rates do not show a clear relationship with the type of convergent boundary (Figure 4). Although the highest rates for each type reflect Yonekura's [1983] hypothesized relationship, the range of uplift rates for all three convergent boundary classes extends through the entire spectrum from little or no uplift to the highest observation. Collision zones and ocean-to-continent subduction zones, which include southern coastal Oregon, show an especially wide range of late Quaternary uplift rates. The rather low uplift rates reported for north central Chile and the Makran coast of Iran are notable and serve to emphasize the observed variability in uplift rate. It is possible that local structures assume an important, and perhaps the most important, role in determining long-term uplift rates along convergent margins (see McInelly and Kelsey [this issue] and Kelsey [1990] for examples from the Oregon coast). West and McCrumb [1988] emphasized that late Quaternary uplift rates for coastal Oregon are significantly lower than those reported for other subduction zones. However, our compilation suggests that the uplift rate at Cape Blanco is higher than many of those reported for other subduction zones, and even the lower rate at Coquille Point is similar to, or higher than, uplift rates reported for the Makran coast, Indonesia, Vanuatu, Tonga, the Aleutian Islands, south central Peru, north central Chile, and Barbados.

Uplift rates generated from late Quaternary marine terrace 
data also do not appear to be related to the subduction zone strain classes of Jarrard [1986] (Figure 5). Thus our compilation does not support the hypothesis of Uyeda and Kanamori [1979] that rate of uplift reflects the type of convergent margin. Although Jarrard [1986] based his classification on a variety of strain indicators, the lack of any clear relationship in Figure 5 suggests that factors other than large-scale plate characteristics are at least in part responsible for variation in uplift rates. Local or regional structures that deform the accretionary prism or forearc may be responsible for much of this variation.

\section{Conclusions}

The Whisky Run terrace at Coquille Point and elsewhere where it can be physically traced to Coquille Point is correlative with the well-documented $80 \mathrm{ka}$ high stand of sea, based on a uranium series age for fossil corals. This high sea stand is also represented by the lowest terrace found at Point Arena, California. Amino acid and oxygen isotope data indicate that the lowest terrace at Cape Blanco, herein referred to as the Cape Blanco terrace, is also correlative with the $80 \mathrm{ka}$ high stand of sea and is not $40-60 \mathrm{ka}$, as reported by previous investigators. The next highest terrace at Cape Blanco, informally referred to as the Pioneer terrace, is most likely correlative with the $105 \mathrm{ka}$ high stand of sea.

On the basis of our age determinations for Oregon coastal terraces and a review of marine terraces elsewhere along convergent margins, we make the following conclusions about uplift rates along the southern Oregon coast. First, late Quaternary uplift rate estimates at Cape Blanco are, in general, lower than those estimated by previous workers. The highest possible uplift rate is about $1.49 \mathrm{~m} / \mathrm{kyr}$, but the uplift rate could be as low as $0.81 \mathrm{~m} / \mathrm{kyr}$. At Coquille Point, possible uplift rates range from 0.45 to $1.05 \mathrm{~m} / \mathrm{kyr}$. Point Arena, California, has uplift rate estimates of $0.35-0.52$ $\mathrm{m} / \mathrm{kyr}$, only slightly greater than those reported for similar strike-slip tectonic settings in southern California. Second, when compared to uplift rates derived from marine terraces at other subduction zones, uplift rates in southern coastal Oregon are not unusually high or low.

Quaternary uplift rates derived from marine terraces show little relationship to the style of plate convergence, when uplift rates are classified by type of convergent margin. This observation indicates to us that local structures in the overriding plate may play a large role in uplift rate variability. The type of convergent margin may place an upper limit on possible uplift rate, in which case greater upper limits serve to increase the range of possible uplift rates. In the case of the southern Oregon coast, therefore, variability in uplift rate probably reflects local structures in the overriding plate. For the southern Cascadia subduction zone and other convergent margins we conclude that uplift rate is probably not a simple index of the potential for great earthquakes.

Acknowledgments. Field work for Kelsey and McInelly was supported in part by the Earthquake Hazards Reduction Program of the U.S. Geological Survey (award 14-08-0001-G1387). Z. R. Muhs, T. R. Rowland, and R. R. Rowland helped collect modern shells at Bandon for stable isotope analyses. D. P. Adam and C. L. Powell (USGS) kindly loaned some of the fossil shells from Cape Blanco (USGS locality M1452) that were used in our analyses. We thank C. A. Bush (USGS) for help with data processing of the U series analyses. D. Merritts, A. L. Bloom, A. R. Nelson, and C. W. Naeser read an earlier version of the manuscript and provided helpful comments for its improvement.

\section{REFERENCES}

Adams, J., Active deformation of the Pacific Northwest continental margin, Tectonics, 3, 449-472, 1984.

Addicott, W. O., A late Pleistocene invertebrate fauna from southwestern Oregon, J. Paleontol., 38, 650-661, 1964.

Aharon, P., and J. Chappell, Oxygen isotopes, sea level changes and the temperature history of a coral reef environment over the last $10^{5}$ years, Palaeogeogr. Palaeoclimatol. Palaeoecol., 56, 337379, 1986.

Atwater, B. F., Evidence for great Holocene earthquakes along the outer coast of Washington State, Science, 236, 942-944, 1987.

Baldwin, E. W., Geology of Oregon, 3rd ed., Kendall-Hunt, Dubuque, Iowa, 1981.

Beaulieu, J. D., and P. W. Hughes, Environmental geology of western Coos and Douglas counties, Oregon, Bull. Oreg. Dep. Geol. Miner. Ind., 87, 1-148, 1975.

Beaulieu, J. D., and P. W. Hughes, Land-use geology of western Curry County, Oregon, Bull. Oreg. Dep. Geol. Miner. Ind., 90, $1-148,1976$.

Bender, M. L., R. G. Fairbanks, F. W. Taylor, R. K. Matthews, J. G. Goddard, and W. S. Broecker, Uranium-series dating of the Pleistocene reef tracts of Barbados, West Indies, Geol. Soc. Am. Bull., Part 1, 90, 577-594, 1979.

Berryman, K. R., Y. Ota, and A. G. Hull, Holocene paleoseismicity in the fold and thrust belt of Hikurangi subduction zone, eastern North Island, New Zealand, Tectonophysics, 163, 185-195, 1989.

Bloom, A. L., W. S. Broecker, J. M. A. Chappell, R. K. Matthews, and K. J. Mesolella, Quaternary sea level fluctuations on a tectonic coast: New ${ }^{230} \mathrm{Th} /{ }^{234} \mathrm{U}$ dates from the Huon Peninsula, New Guinea, Quat. Res. N. Y., 4, 185-205, 1974.

Bradley, W. C., and G. B. Griggs, Form, genesis, and deformation of central California wave-cut platforms, Geol. Soc. Am. Bull., 87, 433-449, 1976.

Chappell, J., Geology of coral terraces, Huon Peninsula, New Guinea: A study of Quaternary tectonic movements and sea level changes, Geol. Soc. Am. Bull., 85, 553-570, 1974.

Chappell, J., and N. J. Shackleton, Oxygen isotopes and sea level, Nature, 324, 137-140, 1986.

Chappell, J., and H. H. Veeh, Late Quaternary tectonic movements and sea level changes at Timor and Atauro Island, Geol. Soc. Am. Bull., 89, 356-368, 1978.

Dodge, R. E., R. G. Fairbanks, L. K. Benninger, and F. Maurrasse, Pleistocene sea levels from raised coral reefs of Haiti, Science, $219,1423-1425,1983$.

Fairbanks, R. G., and R. K. Matthews, The marine oxygen isotope record in Pleistocene coral, Barbados, West Indies, Quat. Res. N. Y., 10, 181-196, 1978 .

Griggs, A. B., Chromite-bearing sands of the southern part of the coast of Oregon, U.S. Geol. Surv. Bull., 945-E, 113-150, 1945.

Heaton, T. H., and S. H. Hartzell, Source characteristics of hypothetical subduction earthquakes in the northwestern United States, Bull. Seismol. Soc. Am., 76, 675-708, 1986.

Heaton, T. H., and S. H. Hartzell, Earthquake hazards on the Cascadia subduction zone, Science, 236, 162-168, 1987.

Heaton, T. H., and H. Kanamori, Seismic potential associated with subduction in the northwestern United States, Bull. Seismol. Soc. Am., 74, 933-941, 1984.

Hsu, J. T., A. L. Bloom, and J. F. Wehmiller, Quaternary tectonism over the subducting Nazca Ridge, south-central Peru, paper presented at XII Congress, Int. Quat. Assoc., Ottawa, Ont., 1987.

Iso, N., A. Okada, Y. Ota, and T. Yoshikawa, Fission-track ages of late Pleistocene tephra on the Bay of Plenty coast, North Island, New Zealand, N. Z. J. Geol. Geophys., 25, 295-303, 1982.

James, N. P., E. W. Mountjoy, and A. Omura, An early Wisconsin reef terrace at Barbados, West Indies, and its climatic implications, Geol. Soc. Am. Bull., 82, 2011-2018, 1971.

Janda, R. J., Age and correlation of marine terraces near Cape Blanco, Oregon, Geol. Soc. Am. Abstr. Programs, 3, 29-30, 1969. Jarrard, R. D., Relations among subduction parameters, Rev. Geophys., 24, 217-284, 1986.

Jennings, C. W., and R. G. Strand, Geologic map of California, 
Ukiah sheet, scale 1 : 250,000, Calif. Dep. of Nat. Resour., Div. of Mines and Geol., Sacramento, 1960.

Jouannic, C., F. W. Taylor, A. L. Bloom, and M. Bernat, Late Quaternary uplift history from emerged reef terraces on Santo and Malekula Islands, central New Hebrides island arc, Tech. Bull. 3 , pp. 91-108, Econ. and Soc. Comm. for Asia and the Pac. and the Comm. for Coord. of Joint Prospect. for Miner. Resour. in S. Pac. Offshore Areas, Suva, Fiji, 1980.

Jouannic, C., C. T. Hoang, W. S. Hantoro, and R. M. Delinom, Uplift rate of coral reef terraces in the area of Kupang, West Timor: Preliminary results, Palaeogeogr. Palaeoclimatol. Palaeoecol., 68, 259-272, 1988.

Kaizuka, S., T. Matsuda, M. Nogami, and N. Yonekura, Quaternary and recent seismic crustal movements in the Arauco Peninsula and its environs, central Chile, Geogr. Rep. Tokyo Metrop. Univ., 8, 1-49, 1973.

Kaufman, A., W. S. Broecker, T.-L. Ku, and D. L. Thurber, The status of U-series methods of mollusk dating, Geochim. Cosmochim. Acta, 35, 1155-1183, 1971.

Kelsey, H. M., 3000-year-old elevated beach berm south of Cape Blanco, Oregon: Probable evidence of late Holocene tectonic uplift, Geol. Soc. Am. Abstr. Programs, 21, 101, 1989.

Kelsey, H. M., Quaternary deformation of marine terraces on Cascadia subduction zone near Cape Blanco, Oregon, Tectonics, in press, 1990.

Kelsey, H. M., and G. A. Carver, Late Neogene and Quaternary tectonics associated with northward growth of the San Andreas transform fault, northem California, J. Geophys. Res., 93, 4797$4819,1988$.

Kennedy, G. L., Pleistocene paleoecology, zoogeography and geochronology of marine invertebrate faunas of the Pacific Northwest coast (San Francisco Bay to Puget Sound), Ph.D. thesis, 824 pp., Univ. Calif., Davis, 1978.

Kennedy, G. L., Pleistocene marine invertebrates from the Mendocino coast, northern California, West. Soc. Malacol. Annu. Rep., $13,13-14,1981$.

Kennedy, G. L., and J. F. Wehmiller, Paleoclimatic implications of Quaternary marine invertebrate faunas from southwestern Santa Barbara County, California, Annu. Rep. 18, pp. 22-23, West. Soc. of Malacol., 1986.

Kennedy, G. L., K. R. Lajoie, and J. F. Wehmiller, Aminostratigraphy and faunal correlations of late Quaternary marine terraces, Pacific coast, USA, Nature, 299, 545-547, 1982.

Kern, J. P., Origin and history of upper Pleistocene marine terraces, San Diego, California, Geol. Soc. Am. Bull., 88, 1553-1566, 1977.

Konishi, K., Diverse plate convergence as deduced from raised coral reefs since the last interglacial, Quat. Res. Tokyo, 19, 241-250, 1980.

Konishi, K., A. Omura, and O. Nakamichi, Radiometric coral ages and sea level records from late Quaternary reef complexes of the Ryukyu Islands, Proc. Int. Coral Reef Symp. 2nd, 2, 595-613, 1974.

Ku, T.-L., and J. P. Kern, Uranium-series age of the upper Pleistocene Nestor terrace, San Diego, California, Geol. Soc. Am. Bull., 85, 1713-1716, 1974.

Lajoie, K. R., Coastal tectonics, in Active Tectonics, pp. 95-124, National Academy Press, Washington, D. C., 1986.

Lajoie, K. R., J. F. Wehmiller, and G. L. Kennedy, Inter- and intrageneric trends in apparent racemization kinetics of amino acids in Quaternary mollusks, in Biogeochemistry of Amino Acids, edited by P. E. Hare, T. C. Hoering, and K. King, Jr., pp. 305-340, John Wiley, New York, 1980.

Lajoie, K. R., A. M. Sarna-Wojcicki, and Y. Ota, Emergent Holocene marine terraces at Ventura and Cape Mendocino, California-Indicators of high tectonic uplift rates, Geol. Soc. Am. Abstr. Programs, 14, 178, 1982.

Lecolle, J., and M. Bernat, Late Quaternary surrection history of Efate Island, New Hebrides island arc (Vanuatu) Th/U dates from uplifted terraces, Proc. Int. Coral Reef Congr. 5th, 3, 179-184, 1985.

Leonard, E. M., J. F. Wehmiller, and G. H. Miller, Tectonic uplift rates along the coast of north-central Chile: Preliminary data from amino acid ratios, Geol. Soc. Am. Abstr. Programs, 16, 574, 1984.

Machida, H., Pleistocene sea level of south Kanto, Japan, analysed by tephrochronology, Bull. R. Soc. N. Z., 13, 215-222, 1975.

Matsuda, T., Y. Ota, M. Ando, and N. Yonekura, Fault mechanism and recurrence time of major earthquakes in southern Kanto district, Japan, as deduced from coastal terrace data, Geol. Soc. Am. Bull., 89, 1610-1618, 1978.

Matthews, R. K., The $\delta^{18} \mathrm{O}$ signal of deep-sea planktonic foraminifera at low latitudes as an ice-volume indicator, $S$. Afr. J. Sci., 81 , 274-275, 1985.

McCulloch, D. S., Regional geology and hydrocarbon potential of offshore central California, in Geology and Resource Potential of the Continental Margin of Western North America and Adjacent Ocean Basins-Beaufort Sea to Baja California, Earth Sci. Ser., vol. 6, edited by D. W. Scholl, A. Grantz, and J. G. Vedder, pp. 353-401, Circum-Pacific Council for Energy and Mineral Resources, Houston, Tex., 1987.

McInelly, G. W., and H. M. Kelsey, Holocene and late Pleistocene tectonic deformation in the Cape Arago-Bandon region of coastal Oregon, as deduced from uplifted and deformed wave-cut platforms, J. Geophys. Res., this issue.

McInelly, G. W., H. M. Kelsey, and A. R. Nelson, Late Pleistocene and Holocene tectonic deformation of the Whisky Run wave-cut platform in the Cape Arago-Coos Bay area, coastal Oregon, Geol. Soc. Am. Abstr. Programs, 21, 115, 1989.

Mesolella, K. J., R. K. Matthews, W. S. Broecker, and D. L. Thurber, The astronomical theory of climatic change: Barbados data, J. Geol., 77, 250-274, 1969.

Miller, G. H., Aminostratigraphy of Baffin Island shell-bearing deposits, in Quaternary Studies on Baffin Island, West Greenland, and in Baffin Bay, edited by J. T. Andrews, pp. 394-427, George Allen and Unwin, Boston, Mass., 1985.

Muhs, D. R., and G. L. Kennedy, An evaluation of uranium-series dating of fossil echinoids from southern California Pleistocene marine terraces, Mar. Geol., 69, 187-193, 1985.

Muhs, D. R., and T. K. Kyser, Stable isotope compositions of fossil mollusks from southern California: Evidence for a cool last interglacial ocean, Geology, 15, 119-122, 1987.

Muhs, D. R., and B. J. Szabo, Uranium-series age of the Eel Point terrace, San Clemente Island, California, Geology, 10, 23-26, 1982.

Muhs, D. R., G. L. Kennedy, and G. H. Miller, New uranium-series ages of marine terraces and late Quaternary sea level history, San Nicolas Island, California, Geol. Soc. Am. Abstr. Programs, 19 , 780-781, 1987.

Muhs, D. R., G. L. Kennedy, and T. K. Rockwell, Uranium-series ages of corals from marine terraces, Pacific coast of North America: Implications for the timing and magnitude of late Pleistocene sea level changes, in Programs and Abstracts of the 10th Biennial Meeting, p. 140, Illinois State Water Survey, Urbana, 1988.

Neef, G., and C. Hendy, Late Pleistocene-Holocene acceleration of uplift rate in southwest Erromango Island, southern Vanuatu, south Pacific: Relation to growth of the Vanuatuan mid sedimentary basin, J. Geol., 96, 481-494, 1988.

Neef, G., and H. H. Veeh, Uranium series ages and late Quaternary uplift in the New Hebrides, Nature, 269, 682-683, 1977.

Omura, A., Uranium-series age of the Hiradoko and Uji shell beds, Noto Peninsula, central Japan, Trans. Proc. Palaeontol. Soc. Jpn., 117, 247-253, 1980.

Omura, A., New information on radiometric ages of fossil corals from the Hateruma Island, Ryukyu Islands, Quat. Res. Tokyo, 22, 19-22, 1983.

Omura, A., Uranium-series age of the Riukiu Limestone on Hateruma Island, southwestern Ryukyus, Trans. Proc. Palaeontol. Soc. Jpn., 135, 415-426, 1984.

Ota, Y., Marine terraces and active faults in Japan with special reference to co-seismic events, in Tectonic Geomorphology, edited by M. Morisawa and J. T. Hack, pp. 345-366, George Allen and Unwin, Boston, 1985.

Ota, Y., Marine terraces as reference surfaces in late Quaternary tectonics studies: Examples from the Pacific rim, Bull. $R$. Soc. N. Z., 24, 357-375, 1986.

Ota, Y., and K. Hirakawa, Marine terraces and their deformation in Noto Peninsula, Japan Sea side of central Japan, Geogr. Rev. Jpn., 52, 169-189, 1979.

Ota, Y., and N. Hori, Late Quaternary tectonic movement of the Ryukyu Islands, Japan, Quat. Res. Tokyo, 18, 221-240, 1980.

Ota, Y., N. Hori, and A. Omura, Age and deformation of marine 
terraces of Hateruma Island, southwest Japan, paper presented at XI Congress, Int. Quat. Assoc., Moscow, 1982.

Page, W. D., J. N. Alt, L. S. Cluff, and G. Plafker, Evidence for the recurrence of large-magnitude earthquakes along the Makran coast of Iran and Pakistan, Tectonophysics, 52, 533-547, 1979.

Pillans, B., Upper Quaternary marine terrace chronology and deformation, South Taranaki, New Zealand, Geology, 11, 292-297, 1983.

Plafker, G., and M. Rubin, Uplift history and earthquake recurrence as deduced from marine terraces on Middleton Island, Alaska, U.S. Geol. Surv. Open File Rep., 78-943, 687-721, 1978.

Rockwell, T. K., D. R. Muhs, G. L. Kennedy, M. E. Hatch, S. H. Wilson, and R. E. Klinger, Uranium-series ages, faunal correlations and tectonic deformation of marine terraces within the Agua Blanca fault zone at Punta Banda, northern Baja California, Mexico, in Geologic Studies in Baja California, edited by P. L. Abbott, pp. 1-16, Pacific Section, Society of Economic Paleontologists and Mineralogists, Los Angeles, Calif., 1989.

Rosholt, J. N., Radioisotope dilution analyses of geological samples using ${ }^{236} \mathrm{U}$ and ${ }^{229} \mathrm{Th}$, Nucl. Instrum. Methods Phys. Res., 223, 572-576, 1984.

Spence, W., Stress origins and earthquake potentials in Cascadia, $J$. Geophys. Res., 94, 3076-3088, 1989.

Szabo, B. J., Uranium-series dating of fossil corals from marine sediments of southeastern United States Atlantic Coastal Plain, Geol. Soc. Am. Bull., 96, 398-406, 1985.

Szabo, B. J., and L. M. Gard, Age of the South Bight II marine transgression at Amchitka Island, Aleutians, Geology, 3, 457-459, 1975.

Szabo, B. J., W. P. McHugh, J. J. Schaber, C. W. Haynes, Jr., and C. S. Breed, Uranium-series dated authigenic carbonates and Acheulian sites in southern Egypt, Science, 243, 1053-1056, 1989.

Taylor, F. W., and A. L. Bloom, Coral reefs on tectonic blocks, Tonga Island arc, Proc. Int. Coral Reef Symp. 3rd, 275-281, 1977.

Taylor, F. W., C. Jouannic, and A. L. Bloom, Quaternary uplift of the Torres Islands, northern New Hebrides frontal arc: Comparison with Santo and Malekula Islands, central New Hebrides frontal arc, J. Geol., 93, 419-438, 1985.

Taylor, F. W., B. L. Isacks, C. Jouannic, A. L. Bloom, and J. Dubois, Coseismic and Quaternary vertical tectonic movements, Santo and Malekula Islands, New Hebrides island arc, J. Geophys. Res., 85, 5367-5381, 1980.

Uyeda, S., and H. Kanamori, Back arc opening and the mode of subduction, J. Geophys. Res., 84, 1049-1061, 1979.

Veeh, H. H., and J. Chappell, Astronomical theory of climatic changes: Support from New Guinea, Science, 167, 862-865, 1970.

Veeh, H. H., and W. C. Burnett, Carbonate and phosphate sedi- ments, in Uranium Series Disequilibrium: Applications to Environmental Problems, edited by R. S. Harmon and M. Ivanovich, pp. 459-480, Clarendon, Oxford, 1982.

Wagner, D. L., and E. J. Bortugno, Geologic map of the Santa Rosa quadrangle, map 2A, 5 sheets, scale 1: 250,000, Reg. Geol. Map. Ser., Calif. Div. of Mines and Geol., Sacramento, Calif., 1982.

Wehmiller, J. F., A review of amino acid racemization studies in Quaternary mollusks: Stratigraphic and chronologic applications in coastal and interglacial sites, Pacific and Atlantic coasts, United States, United Kingdom, Baffin Island, and tropical islands, Quat. Sci. Rev., 1, 83-120, 1982.

Wehmiller, J. F., K. R. Lajoie, K. A. Kvenvolden, E. Peterson, D. F. Belknap, G. L. Kennedy, W. O. Addicott, J. G. Vedder, and R. W. Wright, Correlation and chronology of Pacific coast marine terrace deposits of continental United States by fossil amino acid stereochemistry-Technique evaluation, relative ages, kinetic model ages, and geologic implications, U.S. Geol. Surv. Open File Rep., 77-680, 196 pp., 1977.

West, D. O., and D. R. McCrumb, Coastline uplift in Oregon and Washington and the nature of Cascadia subduction-zone tectonics, Geology, 16, 169-172, 1988.

Yonekura, N., Late Quaternary vertical crustal movements in and around the Pacific as deduced form former shoreline data, in Geodynamics of the Western Pacific-Indonesian Region, Geodyn. Ser., vol. 11, edited by T. W. C. Hilde and S. Uyeda, pp. 41-50, AGU, Washington, D. C., 1983.

Yoshikawa, T., Y. Ota, N. Yonekura, A. Okada, and N. Iso, Marine terraces and their tectonic deformation on the northeast coast of the North Island, New Zealand, Geogr. Rev. Jpn., 53, 238-262, 1980.

H. M. Kelsey and G. W. McInelly, Department of Geology, Western Washington University, Bellingham, WA 98225.

G. L. Kennedy, Section of Invertebrate Paleontology, Los Angeles County Museum of Natural History, Los Angeles, CA 90007.

G. H. Miller, Center for Geochronological Research, INSTAAR, University of Colorado, Boulder, CO 80309.

D. R. Muhs, U.S. Geological Survey, MS 424, Box 25046, Federal Center, Denver, CO 80225.

J. F. Whelan, U.S. Geological Survey, MS 963, Box 25046, Federal Center, Denver, CO 80225.

(Received June 6, 1989; revised November 15, 1989; accepted October 1, 1989.) 